\title{
Los americanismos en el Diccionario de Autoridades. Tratamiento y repercusiones de algunos de éstos en la trayectoria de las distintas ediciones del $D R A E$
}

\author{
Luz Fernández Gordillo \\ El Colegio de México
}

1. Dos autores me anteceden en el estudio de los americanismos en el Diccionario de Autoridades ${ }^{1}(D A)$ : Jesús Gútemberg Bohórquez (1984) y Aurora Salvador Rosa (1985). Estos trabajos me sirvieron como punto de partida para reunir mi corpus, pero como se limitan generalmente a consignar los americanismos que explicitan su localización geográfica, los completé sobre todo con aquéllos sin referencia geográfica, con ella equivocada o no incluida por estos autores y con los que aparecen formando parte de los ejemplos de autoridades de otros americanismos. No puedo tratarlos todos aquí, por lo que anexo un listado con los registros de este material, aclarando que considero americanismo: los regionalismos de alguna parte de Hispanoamérica, o generales en ella, ya sean de ámbito objetivo, es decir los que designan o designaron objetos americanos o realidades exclusivas de América, ya sean los de zona lingüística del español en América².

Mi objetivo en esta ocasión es el de analizar y valorar el tratamiento que se le dio a estas voces a partir de varios casos: aguacate; manato y manatí; batata, papa y patata; pepián y pipián; sabana; y tocayo, constatando su presentación en este primer diccionario académico, y su trayectoria en las diversas ediciones del $D R A E^{3}$.

2. Veamos primero el caso de aguacate, que aparece registrada dos veces: en el artículo de palta, y como entrada, pero con otro significado:

1 Cuyo título completo es Diccionario de la lengua castellana, en que se explica el verdadero sentido de las voces, su naturaleza y calidad, con las phrases o modos de hablar, los proverbios o refranes, y otras cosas convenientes al uso de la lengua (1726-1739).

2 Sigo aquí la terminología empleada en Coseriu (1973: 311). Se trata mayoritariamente de americanismos diacrónicos.

3 Para la consulta de las diversas ediciones del $D R A E$ y la segunda del $D A$, nos servimos del NTLLE vía internet (www.rae.es). 
PALTA. s. f. Fruta de Indias de la figura de la pera. La cáscara es verde, y la médula mantecosa y de mucha substancia. Tiene un hueso mayor, aunque más blando, que el melocotón. En los temperamentos cálidos se dan mayores que en los fríos, y son de mejor calidad. En algunas partes los llaman aguacates, por la semejanza que tienen en el color y la hechura con el aguacate piedra. El árbol que la produce se llama palto. Lat. Palta. Pyrum Indicum. Herr.. Hist. Ind. Dec. 8.lib.4.cap.10. Tienen... paltas y aguacates, que son como grandes peras verdeñales. Acost. Hist. Ind. lib.4. cap. 24. Las paltas al revés son calientes y delicadas.

AGUACATE. s. m. Lo mismo que esmeralda: y sólo se diferencia en que no es tan perfecta, y en que es de hechura redonda, o prolongada. Lat. Smaragdus, i. Lop. Dorot. fol. 36. Hipérboles y energías parecen frutas de las Indias como plátanos y aguacates. Ov. Hist. Chil. fol. 323. Y una cruz de oro guarnecida de preciosos y grandes aguacates $(D A)$.

Como se puede observar, bajo palta sí se precisa que llaman aguacate a la palta en algunas partes de las Indias. Sin embargo, bajo aguacate no se registra esta acepción a pesar de que sí está ejemplificada en la primera autoridad ${ }^{4}$ ni se explicita ninguna referencia geográfica de esta 'esmeralda's.

Ya en la segunda edición del $D A$ se agrega en el artículo de aguacate la acepción del fruto; además, se explicita la designación al árbol que lo produce y se conserva la de 'esmeralda', ahora sí con la indicación sobre el origen de su denominación:

AGUACATE. s. m. Fruta de Indias más grande que las mayores peras, y de su misma figura: la cáscara es de un verde oscuro muy igual y terso, y se quita con facilidad: el hueso es grande a proporción de la fruta, la carne de ella se come, y es un poco amarilla, de las suavidad de la manteca, y del sabor de nueces verdes. Llámase también aguacate el árbol que produce esta fruta. Pomum in America ita dictum ovali forma, vidide, gratum palaro. VARG. Descrip de Ind. pág. 142. Otras frutas cultivan como son aguacates y anones [...].

Estas definiciones se mantienen sin cambio alguno hasta la quinta edición del usual, en la que se presentan reestructuradas en tres acepciones y se reelaboran las definiciones referidas al árbol y a la fruta, conservando igual la acepción de esmeralda. Lo curioso aquí es que la pulpa del aguacate no es lo único comestible, sino también el hueso:

AGUACATE. s. m. Árbol, especie de laurel, de veinte y cinco a treinta piés de altura que conserva las hojas todo el año, $\mathrm{y}$ da un fruto del tamaño de una pera grande, cuya carne así como el hueso son un manjar agradable. Laurus persea.

AGUACATE. La fruta del AGUACATE.

4 Lope de Vega (en La Dorotea): "Hipérboles y energías parecen frutas de las Indias como plátanos y aguacates" (las cursivas son mías).

5 Seguramente este aguacate es una denominación dada por los españoles que llegaron a América y que habían conocido la fruta con este nombre. 
AGUACATE. La esmeralda que tiene figura de perilla. Díjose así por semejanza a la fruta de este nombre. Smaragdus piri formam referens (DRAE-1817).

Y no será sino hasta la undécima ${ }^{6}$ cuando se elimina la información sobre "el hueso comestible"?:

AGUACATE. m. Árbol, especie de laurel, de veinte y cinco a treinta piés de altura que conserva las hojas todo el año, y da un fruto del grosor de una pera grande, cuya carne es un manjar agradable. Laurus persea. || La fruta del AGUACATE. || La esmeralda que tiene figura de perilla. Díjose así por semejanza con la fruta de este nombre. Smaragdus piri formam referens (DRAE-1869).

No me detendré en los cambios poco significativos que se darán en las tres acepciones, y recordaré que en la duodécima edición (DRAE-1884) tuvo lugar la inclusión de las indicaciones etimológicas tal y como las encontramos en la edición más reciente. Sin embargo, no será en ésta sino hasta la siguiente edición, donde se incluya la información etimológica de aguacate. En ella se moderniza la redacción de todos los artículos lexicográficos, y se reformaron las definiciones descriptivas de la flora y la fauna, que pasaron de manifestar el saber tradicional o popular a ofrecer el saber de los especialistas; es decir, se reelaboraron definiciones descriptivas más enciclopédicas y se registraron las referencias al ámbito objetivo original, al menos cuando se tenía ese conocimiento. En el caso del aguacate, esto es palpable en la descripción del árbol:

Aguacate. (Del mej. ahuacaquahuitl.) m. Árbol de América, de la familia de las lauráceas, de ocho a diez metros de altura, con hojas alternas, coriáceas, siempre verdes, flores dioicas, y fruto, parecido a una pera grande y muy sabroso. || Fruto de este árbol. || Esmeralda de figura de perilla. Díjose así por su semejanza con la fruta de este nombre (DRAE-1899).

La siguiente versión del DRAE sólo modifica la abreviatura "mej." por "mejic." de la indicación etimológica. La decimoquinta sustituiría lo "muy sabroso" referido al fruto, con el que termina la primera acepción, por: "de carne blanda, mantecosa e insípida, por lo que se come con sal" y modifica el étimo, sustituyendo ahuacaquahuitl por ahuacatl. La diferencia entre la edición de 1992 y la de 2001 estriba en la acepción tres, en la que se elimina el por qué de la denominación:

aguacate. (Del nahua ahuacatl. fruto del árbol del mismo nombre: testículo) m. Árbol de América, de la familia de las lauráceas, de ocho a diez metros de altura, con hojas alternas, coriáceas, siempre verdes, flores dioicas, y fruto comestible. $\| \mathbf{2}$. Fruto de este árbol. \| 3. Esmeralda de figura de perilla. Díjose así por su semejanza con la fruta de este nombre. $\|[\ldots](D R A E-1992)$

6 Aclaro que en la séptima edición ocurre sólo un cambio poco significativo en la primera acepción: de "y da un fruto del tamaño de una pera grande" a "y da un fruto del grosor de una pera grande".

7 También se manifiesta un cambio de preposición en la tercera acepción. 
aguacate. (Del nahua ahuacatl, fruto del árbol del mismo nombre; testículo) m. Árbol de América, de la familia de las Lauráceas, de ocho a diez metros de altura, con hojas alternas, coriáceas, siempre verdes, flores dioicas, y fruto comestible. $\| \mathbf{2}$. Fruto de este árbol. || 3. Esmeralda de figura de perilla. || 4. Am. Cen. Persona floja o poco animosa. Ú. t. c. adj. (DRAE-2001)

Lo curioso de esta tercera acepción es que se mantenga sin ninguna marca restrictiva, ya sea geolectal, ya de desuso o de poco uso. Digo esto porque no se encuentran ejemplos de aguacate con este significado en ninguno de los dos repertorios (CORDE y CREA) del Banco de datos del español, que la Academia reunió a partir de los ochenta ${ }^{8}$. Y la documentación que ofrece el $D H-1933$ en este artículo podría probar su uso en los siglos XVII, XVIII, y quizá también en el XIX, puesto que recoge la cita de Ovalle del $D A$, la de Mosquera ${ }^{9}$, de 1721, y menciona entre las fuentes lexicográficas además del $D A$, el diccionario de Terreros (1786), el Nuevo Diccionario de Salvá (1847), el de voces cubanas de Pichardo (1875) y el Diccionario de americanismos (1925) de Augusto Malaret, en el que, según el mismo $D H$, aparece señalada como cubanismo. Sin embargo, en las consultas que hice de estos dos últimos diccionarios no hallé esta acepción ${ }^{10}$, ni tampoco en otras fuentes documentales ${ }^{11}$.

3. Pasemos ahora a revisar manatí. El $D A^{12}$ y las tres primeras ediciones del $D R A E$ consignaron exclusivamente la variante manato $^{13}$ con idéntica definición:

MANATO. s. m. Especie de tiburón, que se cría en el mar Índico, el cual tiene la boca como buey y el cuerpo muy grueso, y del largo de veinte pies, cubierto de una

8 Leí 123 concordancias de las distintas formas de aguacate en el CORDE y 404 en el CREA.

9 Lithostática: "A otras que vienen labradas a la manera de perillas, que llaman aguacates por la semejanza a cierta fruta de Indias llamada así, las cuales esmeraldas suelen ser grandes" ( $D H$, s. v. aguacate).

10 Aclaro que de Malaret únicamente pude consultar Malaret (s. v. aguacate) y Pichardo (s. v. aguacate).

11 Tampoco aparece en el CEMC ni en $D E C$. No se refieren a esta acepción ni Buesa (1992) ni el DCECH.

12 Quiero mencionar aquí que el mismo equivalente latino (Vitulus marinus) usado para manato, se emplea en DA para lobo marino. Cambia en la cuarta edición a Lupus marinus y en la quinta a Phoca ursina.

13 Según Cala (2001-2002: 7, n. 2), el polimorfismo de manati y manato tiene que ver con la etimología científica del primero y la popular del segundo. No estoy convencida de esta explicación; creo que el caribeñismo, que significaba 'teta' terminaba en $i$; pero ante la escasez de vocablos con esta terminación, probablemente algunos españoles la modificaron a manato. Galeote (1997: 383) también registra la forma plural malaties en Motolinía. Efectivamente, encontré una sola concordancia en el COR$D E$, de Motolinía: “[...] por este estero suben y se crían en él manatíes o malaties; asímismo se [...]”. Buesa y Enguita (1992: 67) señalan que Oviedo le confirió un origen castellano: "Tiene solas dos manos o brazos cerca de la cabeza, cortos, y por eso los cristianos le llaman manati’". 
piel durísima e impenetrable. El lomo es llano, los ojos pequeños, y el color pardillo. Tiene los pies, que le salen como brazos de los hombros, de los cuales se sirve para nadar. La hembra tiene dos grandes tetas, con cuya leche cría sus hijos, los cuales pare vivos, como animal de tierra. Su carne, siendo fresca, tiene sabor de ternera, y salada tiene gusto de atún, aunque es mejor, y se conserva más tiempo. Su manteca es muy buena y nunca se enrancia y con ella se adoba su mismo cuero, para hacer de él calzado y otras cosas. En la cabeza de este pescado dicen se cría una piedra muy provechosa contra las piedras de los riñones, y para los dolores de ijada. Lat. Vitulus marinus. HuerT. Plin. lib.8. cap. 31. Dicen algunos de los que navegan por el mar de España, que se hallan estos animales en él; pero más ordinario es hallarlos en el mar Índico, donde también se cría el manato $(D A)$.

Aprovechando la información de este artículo, se reelabora en la cuarta edición y se introduce bajo el lema manatí, manteniendo el de manato como sinónimo; este último se conserva con remisión a manatí hasta la edición más reciente.

MANATÍ. s. m. Cetáceo que se cría en el mar índico y en otros mares. Tiene el cuerpo muy grueso cubierto de una piel durísima, y largo como de veinte pies; la boca como de buey, los ojos pequeños, el lomo llano y el color pardillo. Tiene dos pies que le salen como brazos de los hombros, y se sirve de ellos para nadar. La hembra tiene dos grandes tetas, con cuya leche cría sus hijos, los cuales pare vivos como animal de tierra. Su carne siendo fresca sabe a ternera, y salada a atún, aunque es mejor y se conserva más tiempo. Su manteca es muy buena y nunca se enrancia, y con ella se adoba su mismo cuero para hacer de él calzado y otras cosas. Cete marinum sic dictum.

MANATO. $\mathrm{s}$. m. Lo mismo que MANATí (DRAE-1803).

Cambia totalmente esta presentación de manatí en la quinta edición, debido a que los académicos anexaron por primera vez vaca marina en la sección del suplemento, puntualizando en su definición que se trata de una animal "indígena de América y Asia, en donde vive en la desembocadura de sus ríos"14. También en esta edición se incluyó "pez muger. Lo mismo que vaca marina"15.

Así se conservará vaca marina en las ediciones subsecuentes ${ }^{16}$. Sin embargo, en la edición undécima, probablemente por desconocimiento de este mamífero, se sus-

14 La definición completa dice: “Animal indígena de América y Asia, en donde vive en la desembocadura de los ríos. Tiene el cuerpo de catorce pies de largo, cilíndrico, más recio por la parte anterior, de color negruzco, y cubierto de pelos ásperos y ralos. Su cabeza es grande, y la boca está armada de cerdas largas y tiesas; los brazos tienen forma de aleta; y los pies, colocados en la extremidad del cuerpo, están reunidos y representan la misma forma. Las hembras tienen dos tetas con que alimentan sus crías. Trichechus manati"'.

15 Esta designación de pez mujer se conserva en todas las ediciones subsecuentes, y únicamente cambia la remisión en la décima tercera $(D R A E-1899)$ en la que envía al lector a manatí.

16 Con pequeñas modificaciones de redacción y la realización de un equívoco en la sexta edición (se cambió "parte anterior" por "parte interior") que se corrigió en la séptima. 
tituye el inicio de la definición por "especie de foca"17, lo que conllevó al equívoco de que en la siguiente edición se remitiera a $\mathrm{morsa}^{18}$, pero que corrigieron los redactores en la décima tercera edición con la remisión a manatí, como permanece hasta nuestros días.

En esta décima tercera edición (1899) aparece manatí como "voz americana" y en su artículo se detalla: "Vive cerca de las costas orientales de América". Desde el $D R A E-1925$ hasta el DRAE-1970 se informa de su origen, "voz caribe"; a partir de 1984 y en las dos últimas ediciones se consigna "voz caribe o arahuaca" y se puntualiza su ámbito: "Vive cerca de las costas del Caribe y en los ríos de aquellas regiones", no obstante que la especie americana habita en las costas y ríos de América oriental, desde el Golfo de México hasta Brasil. También se corrigió "mamífero pisciforme" por "mamífero sirenio" desde la decimoquinta edición.

En cuanto a la localización que asienta el $D A$ de "mar Índico", podría conjeturar que Plinio, en su texto latino, mencionó un mamífero sirenio semejante al manatí, el también llamado dugón o dugongo ${ }^{19}$, que justamente vive en las costas de océano Índico, y que Jerónimo Gómez de Huerta denominó manato.

Por otra parte, en el artículo de buey de la edición más reciente del DRAE se halla buey marino que, por medio de una remisión a vaca marina, también conduce al usuario de este diccionario hasta manatí. De acuerdo con la trayectoria diccionarística de esta unidad léxica en el $D R A E$, pareciera ser otra designación del mismo animal, aunque de ello no fueron conscientes los académicos sino hasta redactar la quinta versión ${ }^{20}$.

17 "VACA. [...] || marina. Especie de foca que tiene el cuerpo de unos catorce pies de largo, cilíndrico, más recio por la parte anterior, de color negruzco, y cubierto de pelos ásperos y ralos. Su cabeza es grande, y su boca está armada de cerdas largas y tiesas; los brazos tienen forma de aleta; y los pies, colocados en la extremidad del cuerpo, están reunidos y representan la misma forma; las hembras tienen dos tetas con que alimentan sus crías. || [...]" (DRAE-1869).

18 El usuario del DRAE que hubiera consultado manato o manatí en esta edición se debió ver obligado a buscar vaca marina para terminar leyendo la definición de morsa que nada tenía que ver con la de manati: "Mamífero carnicero muy parecido a la foca, del cual se distinguen por dos largos caninos que se prolongan fuera de la mandíbula superior y se aprovechan como marfil" (DRAE-1884, s. v.).

19 Mamífero marino del mismo orden, pero especie distinta (Trichecus senegalensis) que habita en el Mar Rojo y el Océano Índico y que dio origen a la leyenda de la existencia de las sirenas, por lo que también se le denomina pez mujer. El manatí (Trichecus manatus) se halla en América.

20 "BUEY MARINO. Monstruo que se cría en el mar, que por tener alguna semejanza con el buey, es especial la cabeza, se llamó así. Lat. Phoca, ae. Vitulus marinus. MARM. Descripc. de Afric. tom. I. fol. 25. El buey marino que los alarabes llaman Taur bahari, es un animal que se cría en el agua. HuERT. Plin. lib. 6. cap. 34. Allí se ven muchos monstruos lobo marinos como caballos y bueyes" (DA).

"BUEY MARINO. Pez grande de mar, cuya cabeza es semejante a la de la ternera. Marinus vitulus, pho$c a$. MARM. Descripc. de Afric. tom. I. fol. 25. El buey marino, que los alárabes llaman Taur bahari, es un animal que se cría en el agua" $(D A-1770)$. 
Ahora bien, considerando que hay polimorfirmo para designar al manatí, y probablemente también al dugongo (vocablo que no consigna el diccionario académico, tal vez por contar con cuatro ocurrencias en los corpora de la Academia), y que además de manato y vaca marina tenemos buey marino y pez mujer, creo que es necesario verificar la vitalidad de uso de estos vocablos para marcarlos adecuadamente. Según la información del Banco de datos del español de la Real Academia parece tratarse de dos especies de sirenios designados respectivamente manatí y dugongo ${ }^{21}$, y que estos dos nombres tienen como sinónimos vaca marina y pez mu$j^{22}$. Este último compuesto, creo, merecería la marca de "poco usado", y manato, que no tiene ninguna ocurrencia salvo la citada en $D A$, debiera estar marcado, al menos, como "desusado" según los criterios de la Academia. Hay que tener en cuenta, además, al igual que con casos similares a éste en cuanto al polimorfismo, frecuente en la designación de flores y de ciertos animales, que puede deberse a la sinonimia diatópica o diastrática. Recuerdo, como caso extremo, las cerca de treinta designaciones diferentes para 'colibrí' que se usan tan solo en el español de México o, en el español general, el de batata, camote, boniato, buniato, moniato y, en determinado lapso, patata $^{23}$ como designación de la batata. Señalo, además, que la falta de marcas diatópicas y cronológicas ocurre frecuentemente con casi todos los sinónimos que designaban especies endémicas hispanoamericanas (chile, ají, guindilla, pimiento de las Indias, pimiento, guindillo de las Indias).

4. Los artículos de batata, patata y papa constituyen un grupo interesante para su revisión, entre otros por el problema que se manifiesta en la última edición en cuanto a su etimología. Si algún lector quisiera saber actualmente de donde procede el tainismo batata se encontraría con que el diccionario académico no lo saca de dudas:

batata. (De patata).

patata. (Cruce de papa y batata).

papa $^{2}$. (Del quechua papa).

"BUEY MARINO. Pez grande de mar, cuya cabeza es semejante a la de la ternera. Marinus vitulus, pho$c a$ " (DRAE-1780).

"BUEY. s. m. [...] BUEY MARINO. Cetáceo. Lo mismo que VACA MARINA" (DRAE-1817).

"BUEY. s. m. [...] BUEY MARINO. Cetáceo. VACA MARINA" (DRAE-1822).

"BUEY. [...] || marino. Vaca marina" (DRAE-1884).

"buey [...] || marino. vaca marina” (DRAE-1970).

"buey [...] || marino. m. vaca marina" (DRAE-2001).

21 Manatí tiene una frecuencia de 129 ocurrencias en CORDE y 83 en CREA, en tanto que dugongo tiene dos en cada uno de estos repertorios. La variante manato no apareció en estos corpora.

22 Vaca marina con 18 ocurrencias en el CORDE y 5 en el CREA y pez mujer con 4 y 2 respectivamente.

23 Cf. infra. 
Veamos de donde procede este problema. El $D A$ consigna los tres vocablos. Bajo batata, después de la descripción de la planta, se señala que se cultiva en España y que "algunos la llaman patata; y así se halla también escrito; pero lo común es con $b "$ ":

BATATA. s. f. Planta que cultivada y sembrada echa una raíz algo mayor de las
que llaman papas, larga y tortuosa: por de dentro es amarilla, y por defuera parda:
es muy sabrosa y dulce, y aunque de ella se hacen diversos dulces y almíbares muy
delicados, con especialidad es más grata al paladar asada, y rociada después con vi-
no y azúcar. En España se crían muchas en las cercanías de Málaga. Algunos la lla-
man patata; y así se halla también escrito; pero lo común es con b. Lat. Radix quae-
dam optimi saporis, quae Americis partibus advecta, provenit etiam in Hispania.
MARM. Descripc. de Afric. tom. I. fol. 16. El principal sustento de los negros son
unas raíces como batatas. ALFAR. fol. 178. Orejones de Aragón, batatas de Málaga.
AcosT. Hist. Ind. lib.4. cap. 18. Las que agora me ocurren, ultra de las papas que
son lo principal, son ocas, y yanaocas, y camotes, y batatas y xiquimas... Algunos
de estos se han traído a Europa, como son batatas, y se comen por cosa de buen
gusto (DA-1726).

Bajo patata se confirma esta confusión al considerarlo sinónimo de batata ("Lo mismo que batata" ${ }^{24}$. Confusión que se ha testimoniado durante los siglos XVI, XVII y parte del XVIII en numerosos escritores.

En cambio papa, lematizada en plural (papas) y sin marca gramatical ni de número ni de género, o siendo rigurosos, con marca implícita de sustantivo masculino por ser este el género de la acepción que encabeza lo que vendría a ser el artículo lexicográfico, se define como "Ciertas raíces que se crían debajo de la tierra, sin hojas y sin tallo, pardas por de fuera y blancas por de dentro. Es comida insípida”.

PAPA s. m. El Sumo Pontífice Romano [...].

PAPAS Ciertas raíces que se crían debajo de la tierra, sin hojas y sin tallo, pardas por de fuera y blancas por de dentro. Es comida insípida. Lar. Radix quaedam. AcostA. Hist. Ind. lib.4. cap. 17. En cuyo lugar usan los indios otro género de raíces, que llaman papas. HUERT. Plin. lib.6. cap. 34. Cógese poco maíz; pero en lugar de ello hay abundancia de unas raíces llamadas papas, que secas las guardan para todo el año $(D A)$.

En la cuarta edición la entrada se registra en singular, y se suprime la información acerca de su insipidez. Pero no será sino hasta la quinta edición (DRAE-1817), cuando papa se registra como voz sinónima de patata ("Lo mismo que PATATA por la planta y el bulbo") $)^{25}$, aunque sigue apareciendo sin marca gramatical de género:

24 El artículo completo es: "PATATA. s. f. Lo mismo que batata. PragM. DE TASS. año 1680. f.49. La libra de patatas cubiertas, a seis reales y medio. Quev. Orland. Cant. I. Los andaluces de valientes feos, / Cargados de patatas y ceceos" (DA).

25 Galeote (1997: 124-125) ofrece documentación de principios del siglo XVII en Chile que muestran la sinonimia entre papa y patata y señala que aparece así en el Vocabulario de 1789 de Alcedo, donde 
PAPA s.m. El Sumo Pontífice Romano [...].

PAPA. Lo mismo que PATATA por la planta y el bulbo (DRAE-1817).

$\mathrm{Y}$, efectivamente, hallamos bajo patata dos acepciones, una referida a la planta, bajo la cual se precisa el ámbito objetivo originario y su propagación ("Planta indígena de América, y cultivada en casi todas las provincias de España [...]"), y otra al tubérculo ("El bulbo de la raíz de la planta del mismo nombre"):

PATATA. s. f. Planta indígena de América, y cultivada en casi todas las provincias de España. Su raíz es fibrosa y llena de bulbos, los tallos de uno a dos pies de largo, triangulares, lampiños, compuestos de nudos y llenos de ramas; las hojas son grandes y compuestas de otras arrugadas y llenas de pelillos; la flor es pequeña y blanca, y el fruto es redondo, carnoso, amarillento y está lleno de semillas menudas, redondas y chatas. Solanum tuberosus.

PATATA. El bulbo de la raíz de la planta del mismo nombre. Son como redondas, algo chatas, de dos a tres pulgadas de diámetro, cubiertas con una pielecilla blanquecina o rojiza según las castas que hay de ellas, e interiormente blanquizca. Cocida la patata es muy harinosa y un alimento sano y nutritivo. Solani tuberosi tuber.

PATATA DE CAÑA. Lo mismo que PATACA por la planta y el bulbo.

PATATA Gallega. Variedad de la patata común, con la raíz comestible como ella, aunque de color más blanco y de sabor menos fino.

PATATA MANCHEGa. Variedad más fina de la patata y de mejor gusto, con el pellejo de color sonrosado (DRAE-1817).

En la décima edición papa se registra ya con su marca de género:

PAPA m. El sumo pontífice romano, vicario de Cristo, sucesor de san Pedro en [...] || f. PATATA por la planta y el bulbo. || pl. PUCHES. || fam. Cualquier especie de comida. Cibus. || Las sopas blandas que se dan a los niños y por extensión se dice de cualesquiera sopas muy blandas. Papparium (DRAE-1852).

En la edición duodécima y en las dos subsiguientes, el quechuismo papa aparece como latinismo ("Del lat. pāpa, comida"):

Papa. (Del lat. pāpa, comida.) f. Patata. || pl. Puches. || fig. y fam. Cualquier especie de comida. || Sopas blandas que se dan a los niños. || Por ext., cualesquiera sopas muy blandas (DRAE-1884).

que se reinterpretará como quichuismo en las ediciones décimoquinta y siguientes, y no será sino a partir de la decimonovena cuando se consigna como quechuismo propiamente dicho:

papa $^{2}$. (Del quechua papa.) f. Patata, planta. || 2. Patata, tubérculo. || de caña. patata de caña $(D R A E-1970)$.

se asegura que patata es la forma más general. Afirma también que patata 'papa' se extendió por el norte y centro de España durante los siglos XVIII y XIX, mientras que en el sur se conservó el quechuismo papa. 
Con respecto al antillanismo batata $^{26}$, las ediciones duodécima y decimotercera informan del su origen indoamericano: "(Voz americana)"; sin embargo, a partir de la decimocuarta y hasta la más reciente edición, la única indicación etimológica es: "De patata".

La indicación "voz americana" de patata se incluye en las siguientes ediciones: $D R A E-1884, D R A E-1899, D R A E-1914, D R A E-1956$ y $D R A E-1970$; las intermedias, es decir: $D R A E-1925, D R A E-1936$, y $D R A E-1947$, registraron adecuadamente: "De papa, $2^{\circ}$ art., modificado en parte por batata", mejorando en la vigésima: "Voz que resultó de la confusión de las americanas papa y batata", y con mayor claridad en la vigésima primera: "De la confusión de las voces americanas papa y batata", quedando menos nítida en la edición más reciente: "Cruce de papa y batata".

5. El $D A$ incluye la entrada pepián sin ninguna marca y remite a sus lectores a la de pipián ${ }^{27}$. En la décima novena y vigésima ediciones se define, sin indicación del ámbito objetivo, como: "Guiso de carne con tocino y almendra machacada, pipián"; y en la versión de 2001, hallamos dos acepciones que remiten respectivamente a pipián (salsa) y pipián (guiso).

Pipián se registra en el $D A$ con la indicación geográfica de su ámbito: “Guisado indiano"28 explicitando los ingredientes, y olvidando el principal, las pepitas de calabaza, justamente por las que se designó con pepián a este guiso ${ }^{29}$. Este diccionario seleccionó pipián entre las dos variantes, no obstante haber reconocido el uso más general entonces de pepían: "Llámase más comúnmente PEPIÁN aunque con menos propiedad" y agrega: "respecto de que el origen de esta voz es muy natural sea de la latina piper, por ser la pimienta su ingrediente más principal" (las cursivas son mías), confundiendo pimiento colorado -que en México designamos como chile- con la pimienta. Las siguientes diez ediciones la conservan casi igual, sin la explicación sobre el origen del vocablo; la edición undécima la acorta:

Guisado usado en Indias, que se compone de carnero, gallina, pavo u otra ave con tocino gordo y almendra machacada. Llámase también pepián, aunque con menos propiedad,

26 Probablemente se trata de un tainismo (Buesa y Enguita 1992 y DCECH, s. v. batata).

27 Por medio de "véase" (en las siguientes tres ediciones), "lo mismo que" (en el DRAE-1803 y DRAE1817) o directamente (en la decimaoctava).

28 El artículo completo es: "PIPIÁN. s. m. Guisado indiano, que se compone de carnero, gallina, pavo u otra ave, con tocino gordo y almendra machacada. Sazónase con pimiento colorado y especias finas, y se procura que el caldo salga espeso. Suelen darle color más encendido con achiote. Llámase más comúnmente pepián, aunque con menos propiedad; respecto de que el origen de esta voz es muy natural sea de la latina piper, por ser la pimienta su ingrediente más principal. Lat. Condimentum indicum ex piperitide, amygdalisque pinsis, rubeoe colore distinctum" $(D A)$.

$29 C f$. DMej, s. v. pipián y la ocurrencia de fray Bernardino de Sahagún, citada en Alatorre (2001): "cazuela de guajolote que los naturales hacen con chile vermejo y con tomates y pepitas de calabaza molidas, que se llama ahora este manjar pipián". 
y sin esta explicación y el cambio de "Indias" a "América" en la duodécima. A partir de la siguiente hasta la vigésimo primera como: "Guiso americano que se compone de carnero, gallina, pavo u otra ave con tocino gordo y almendra machacada". En la edición más reciente ofrece un artículo totalmente modificado sin indicación etimológica; en él, la acepción que estudiamos se ofrecen en dos con la marca geolectal de "México":

pipián. m. [...] 5. Méx. Salsa de semillas de calabaza, o almendras o maíz tostado, molidos con chile verde. \|6. Méx. Guiso de carne o de ave con esta salsa.

El problema aquí no es solo que no hay información etimológica. He señalado ${ }^{30}$ que la forma originaria fue pepián formado a partir de pepita, por las pepitas de calabaza, y por asimilación, surgió pipián. El problema es que la definición no está completa, ya que hay dos tipos de salsa una roja elaborada con chile ancho, pasilla u otros rojos, según las regiones, y una verde, como la indicada en la definición. Por otra parte, el pipián tradicional no se elabora con almendras. Al parecer la fuente de la que se sirvió la edición más reciente del $D R A E$ para esta definición no fue muy adecuada.

6. El $D A$ registra la entrada sábana y como subentrada de ésta, considerándola también esdrújula, el tainismo sabana explicado de esta forma: "Por semejanza se llama el plano grande nevado, que está muy blanco, e igual" y sin ninguna autoridad. La semejanza que los académicos creyeron identificar entre el significado de sábana y el de sabana -por desconocimiento de esa configuración de terreno- determinó la representación esdrújula de este vocablo, que permaneció así en las cuatro ediciones siguientes, marcada "metafórica" y definida como: "El plano grande nevado, que está muy blanco, e igual".

No obstante haber pasado como préstamo al francés y al inglés desde el siglo XVI (savane en francés, savanna en inglés), este caribeñismo se elimina en el $D R A E$ desde su quinta edición, para reencontrarlo, ahora sí como sabana, en un artículo propio a partir de la novena edición, explicado en ésta y en las dos siguientes como: "Páramo, llanura, sin árboles, extensa y arenosa. Es voz de mucho uso en América"; en forma más sucinta, en el $D R A E-1884$ y el $D R A E-1899$ : "Campo, llanura dilatada, en América."; y con su información de origen en las siguientes siete ediciones como: "Voz caribe", modificada en las dos últimas por "De origen caribe". En cuanto a la definición permaneció: "f. En América, llanura, en especial si es muy dilatada, sin vegetación arbórea" desde la decimocuarta hasta la vigésima, en la que se suprimió la indicación geográfica, considerándola de uso general. De la misma manera se halla en las dos ediciones más recientes.

30 A partir de la información del DMej y Alatorre (2001). 
Curioso resulta sabana junto a pampa, estepa, llano, llanura y páramo. Pareciera que el término genérico para designar una gran extensión de tierra plana sea el de llanura, y con vegetación arbórea escasa, sea el de páramo o llano, al menos en el español mexicano. Los demás son casi nombres propios, la pampa para designar los llanos argentinos, la estepa para los llanos rusos y la sabana para los llanos venezolanos esencialmente.

7. Tocayo, ya, definido en el $D A$ como: "Lo mismo que colombroño", contiene erróneamente como marca gramatical la de adjetivo, en tanto que colombroño sí se marca como sustantivo masculino. Ese error lo corrigieron los académicos en la undécima edición (DRAE-1869). La definición sinonímica se modifica en la cuarta edición (DRAE-1803) "Cualquiera de dos o más que tienen un mismo nombre" 31 , precisada en la undécima: "Cualquier persona respecto de otra u otras que tienen su mismo nombre", modernizada en la siguiente y mantenida así hasta la edición actual: "Respecto de una persona, otra que tiene su mismo nombre". En el DRAE1899 se informa sobre su etimología: "De la fórmula matrimonial romana $U b i$ tu Caius ego Caia", la cual se conserva únicamente en la edición del DRAE-1914. A partir de 1925, el $D R A E$ se abstiene de incluir algún dato en este rubro, ni siquiera el de origen incierto que reconocen Corominas y Pascual en su $D C E C H$, no obstante su defensa de la hipótesis de la frase ritual romana ${ }^{32}$ Ubi tu Cajus, ibi ego Caja, como la que dio origen al "adjetivo" tocayo (reiterando el error de la marca gramatical de los diccionarios académicos) y el rechazo tajante a aceptar que se trata de un nahuatlismo. Los defensores del origen náhuatl se apoyan en la existencia de "un tocáitl 'nombre' y un tocayotia 'nombrar a alguno, llamarlo por su nombre" 33 y suponen que tocayo, junto con chocolate, tomate, tiza, galpón, etc., emigró a España, donde probablemente se sintió más precisa y ligera que el sustantivo masculino "colombroño" ${ }^{34}$, cuyo femenino no se reconoce.

8. Ahora bien, las confusiones y equivocaciones que hemos visto en estos pocos casos sirven para ilustrar las dificultades que tienen que enfrentar los lexicógrafos. No obstante el avance que ha habido en la aclaración de muchas etimologías, el $D R A E$ no asienta aquéllas que aún se siguen discutiendo ${ }^{35} \mathrm{y}$, en general, apunta el

31 Probablemente redactado así a partir de la definición de colombroño en el $D A$ : "El que tiene el mismo nombre que otro".

32 Insertada en el Diccionario de Vicente Batús (1828-1831).

33 Véase Alatorre (2001: 21-23).

34 En cuanto a este término, el $D A$ lo marca s. m. y lo define como: "El que tiene el mismo nombre que otro $[\ldots]$ "..

35 Como ocurre con tocayo, como acabamos de comentar. 
origen de los indoamericanismos, pero no transcribe siempre los étimos, ni siquiera los documentados. Probablemente, si lo hiciera, evitaría errores como el de batata; considero que, en este rubro, le falta sistematizar una forma de presentación.

Otro problema lo constituye el mantener, sin marcas geográficas o cronológicas, entradas y acepciones que las requieren. De los casos revisados, haría falta en aguacate 'esmeralda', en pepián, en manato, pez mujer, buey marino, vaca marina y en patata con el sentido de 'batata'.

Sin embargo, creo que la dificultad más grande en la definición de americanismos de ámbito es el de no conocer directamente la realidad que se describe. Esto, justamente, obliga a los lexicógrafos a confiar en las definiciones que le proporcionan cada una de las Academias Correspondientes y que no resulta suficiente y adecuada en todos los casos, como por ejemplo sucede en pipián. Por lo que toca a las designaciones de la flora y fauna endémica, la definición enciclopédica, creo que sigue siendo problemática en cuanto se define con términos más o menos especializados de la zoología y botánica, incumpliendo el principio de transparencia, aunque se registren en las nomenclaturas para que resulten definiciones autosuficientes. Se podría problematizar este tratamiento y reflexionar si no sería mejor que las definiciones ofrecieran el saber no especializado o tradicional, al que se apegó más el $D A$ que el actual $D R A E$, y que respondería mejor al modelo del diccionario de lengua como diccionario cultural.

\section{REFERENCIAS BIBLIOGRÁFICAS}

Alatorre, Antonio (2001): "Sobre americanismos en general y mexicanismos en especial”, Nueva Revista de Filología Hispánica, XLIX, 1, pp. 1-51.

BoHóRQuEZ, Jesús Gútemberg (1984): Concepto de 'americanismo'en la historia del español. Punto de vista lexicológico y lexicográfico, Bogotá, Instituto Caro y Cuervo.

Buesa Oliver, Tomás y José M. Enguita Utrilla (1992): Léxico del español de América: su elemento patrimonial e indígena, Madrid, Mapfre.

Cala Carvajal, Rafael (2001-2002): "La coherencia en lexicografía. El caso de algunos indoamericanismos en el Diccionario de Autoridades (1726-1739)", Revista de Lexicografía, vIII, pp. 7-24.

CEMC. Diccionario del Español de México (1974): Corpus del español mexicano contemporáneo (1921-1974), México, El Colegio de México.

CORDE. Real ACademia Española: Corpus Diacrónico del Español, repertorio del Banco de datos del español, http://www.rae.es.

COSERIU, Eugenio (1973 [1962]): Teoría del lenguaje y lingüistica general: cinco estudios. Madrid, Gredos. 
CREA. Real Academia Española: Corpus de Referencia del Español Actual, repertorio del Banco de datos del español, http://www.rae.es.

DCECH. Corominas, Joan y José A. Pascual (1980-1991): Diccionario crítico etimológico castellano e hispánico, Madrid, Gredos.

DA. Real Academia Española (1969 [1726-1739]): Diccionario de Autoridades, Madrid, Gredos [edición facsímil].

DEC. HAENSCH, Günther y Reinhold Werner (2000): Diccionario del español de Cuba. Español de Cuba-Español de España, Madrid, Gredos.

DH. Real Academia Española (1933): Diccionario histórico de la lengua española, Madrid, Espasa-Calpe.

DRAE-2001. ReAl ACADEMIA EsPañola (200122): Diccionario de la lengua española, Madrid, Espasa-Calpe.

GALEOTE, M. (1997): Léxico indigena de flora y fauna en tratados sobre las Indias Occidentales de autores andaluces, Granada, Universidad de Granada.

NTLLE. Real Academia Española: Nuevo Tesoro Lexicográfico de la Lengua Española, www.rae.es/?//buscon.rae.es/ntlle/SrvltGUILoginNtlle.

SAlvador Rosa, Aurora (1985): "Las localizaciones en el Diccionario de Autoridades”, Lingüística Española Actual, 7, pp. 103-139.

Dmej. Santamaría, Francisco J. (1959): Diccionario de mejicanismos razonado; comprobado con citas de autoridades; comparado con el de americanismos y con los vocabularios provinciales de los más distinguidos diccionaristas hispanoamericanos, México, Porrúa.

Malaret, Augusto (1946³ [1925]): Diccionario de americanismos, Buenos Aires, Emecé.

PichARDO, Esteban (1849): Diccionario provincial casi-razonado de voces cubanas, La Habana, M. Soler [Madrid, Mapfre, Fundación histórica Tavera, Publicaciones digitales]. 


\begin{tabular}{|c|c|c|c|c|c|c|c|c|c|c|c|c|c|c|c|}
\hline & 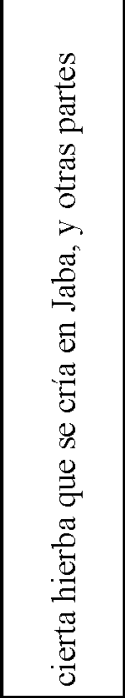 & 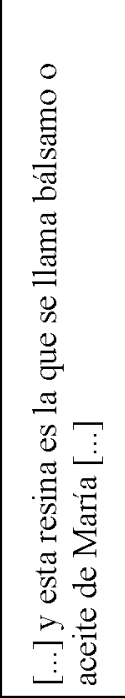 & 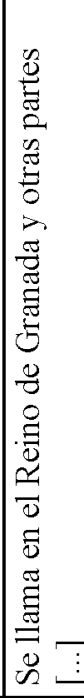 & 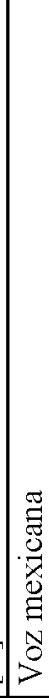 & 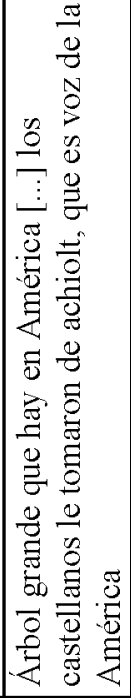 & 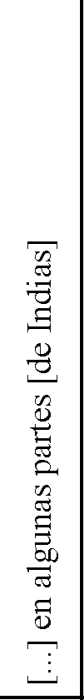 & & & 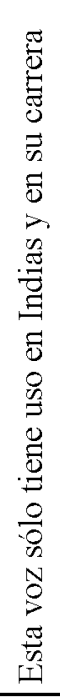 & 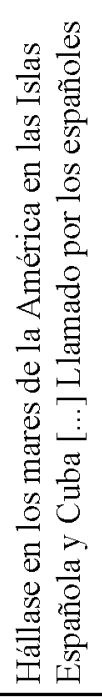 & 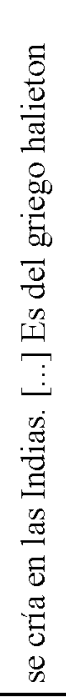 & & 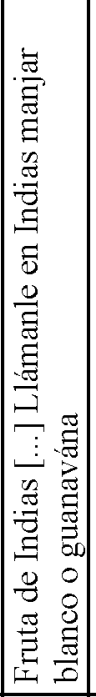 & 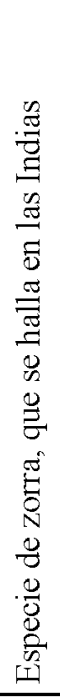 & 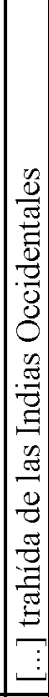 \\
\hline 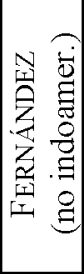 & & 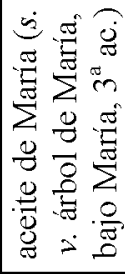 & & & & & & & 莺 & 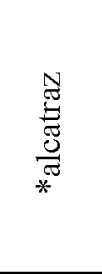 & $\frac{\frac{0}{2}}{\pi}$ & & & & \\
\hline & & - & & & & & & & $\mathrm{d}$ & $m$ & $\nabla$ & & & & \\
\hline 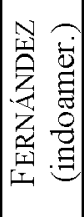 & & & & 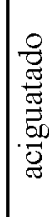 & 递 & 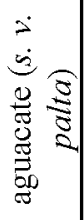 & $\mid$ & 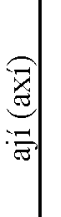 & & & & 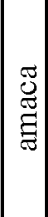 & 苂 & 䓃 & 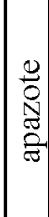 \\
\hline & & & & - & $N$ & $m$ & $\nabla 1$ & in & & & & 0 & $r$ & $\infty$ & $a$ \\
\hline 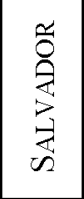 & & & & 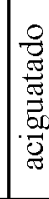 & 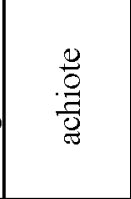 & 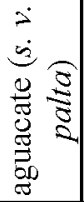 & & & & & & & $\begin{array}{l}\overparen{\Xi} \\
\stackrel{\Xi}{\Xi}\end{array}$ & & 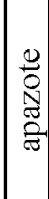 \\
\hline & & & & - & ণ & $m$ & & & & & & & $\nabla$ & & in \\
\hline 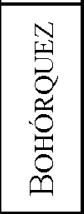 & 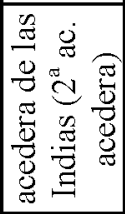 & & 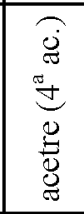 & 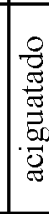 & $\begin{array}{l}\frac{0}{0} \\
\frac{0}{0} \\
\frac{0}{0}\end{array}$ & & & & 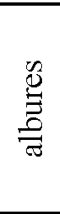 & 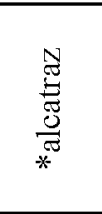 & $\frac{8}{\frac{0}{\pi}}$ & & $\begin{array}{l}\stackrel{\Xi}{0} \\
\stackrel{\Xi}{\Xi}\end{array}$ & & \\
\hline & - & & $N$ & $m$ & $\forall$ & & & & in & 6 & $r$ & & $\infty$ & & \\
\hline
\end{tabular}




\begin{tabular}{|c|c|c|c|c|c|c|c|c|c|c|c|}
\hline \multirow[t]{3}{*}{ 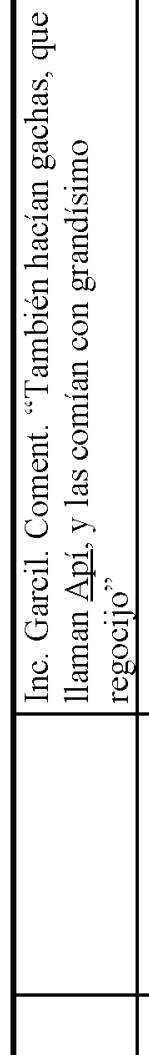 } & & & 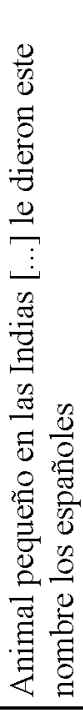 & 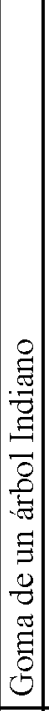 & 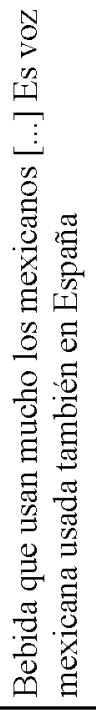 & 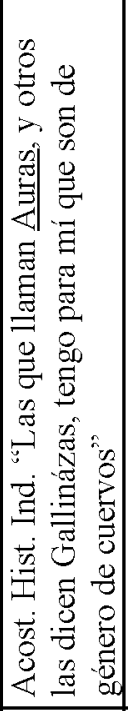 & 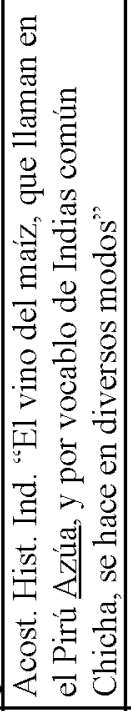 & 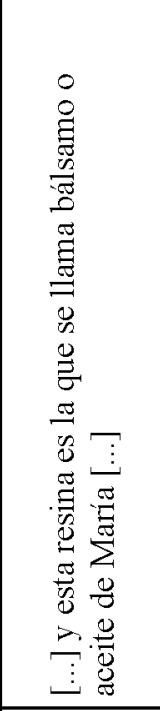 & 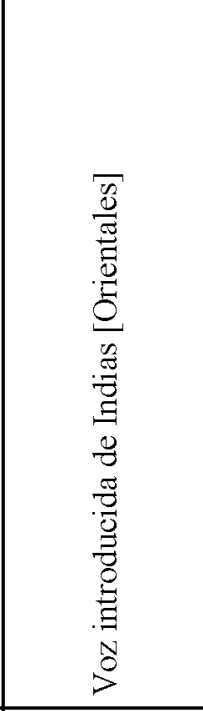 & 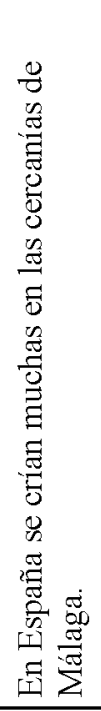 & 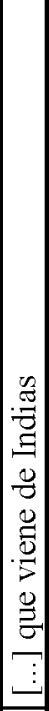 \\
\hline & & & 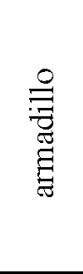 & & & & & 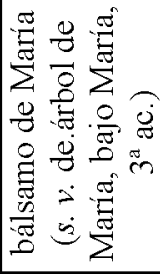 & & & \\
\hline & & & in & & & & & 6 & & & \\
\hline 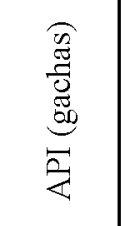 & 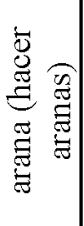 & 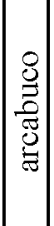 & & & $\frac{0}{\frac{0}{0}}$ & 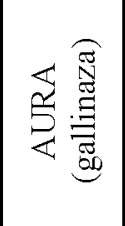 & 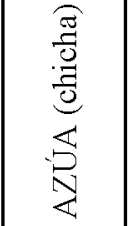 & & & 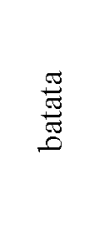 & 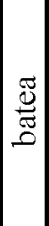 \\
\hline 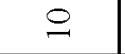 & $=$ & 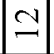 & & & $\stackrel{m}{=}$ & 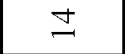 & 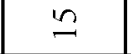 & & & $\stackrel{0}{=}$ & $=$ \\
\hline & & & & & $\frac{0}{\frac{0}{0}}$ & & & & & & \\
\hline & & & & & 6 & & & & & & \\
\hline & & & 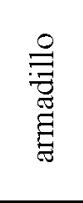 & 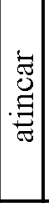 & $\frac{0}{0}$ & & & & 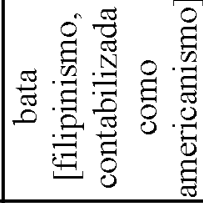 & & \\
\hline & & & $a$ & 9 & 二 & & & & 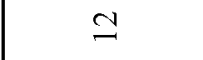 & & \\
\hline
\end{tabular}




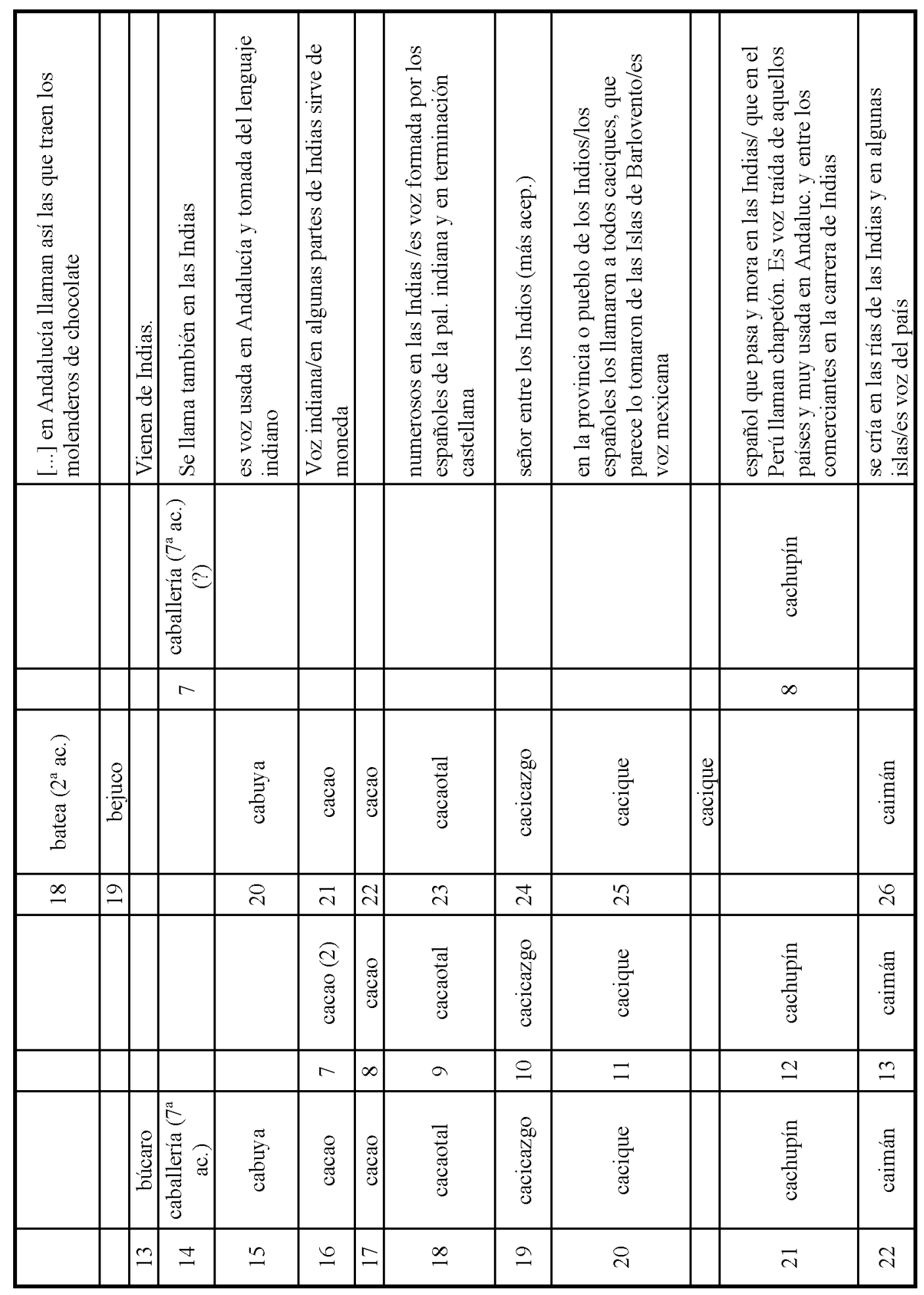




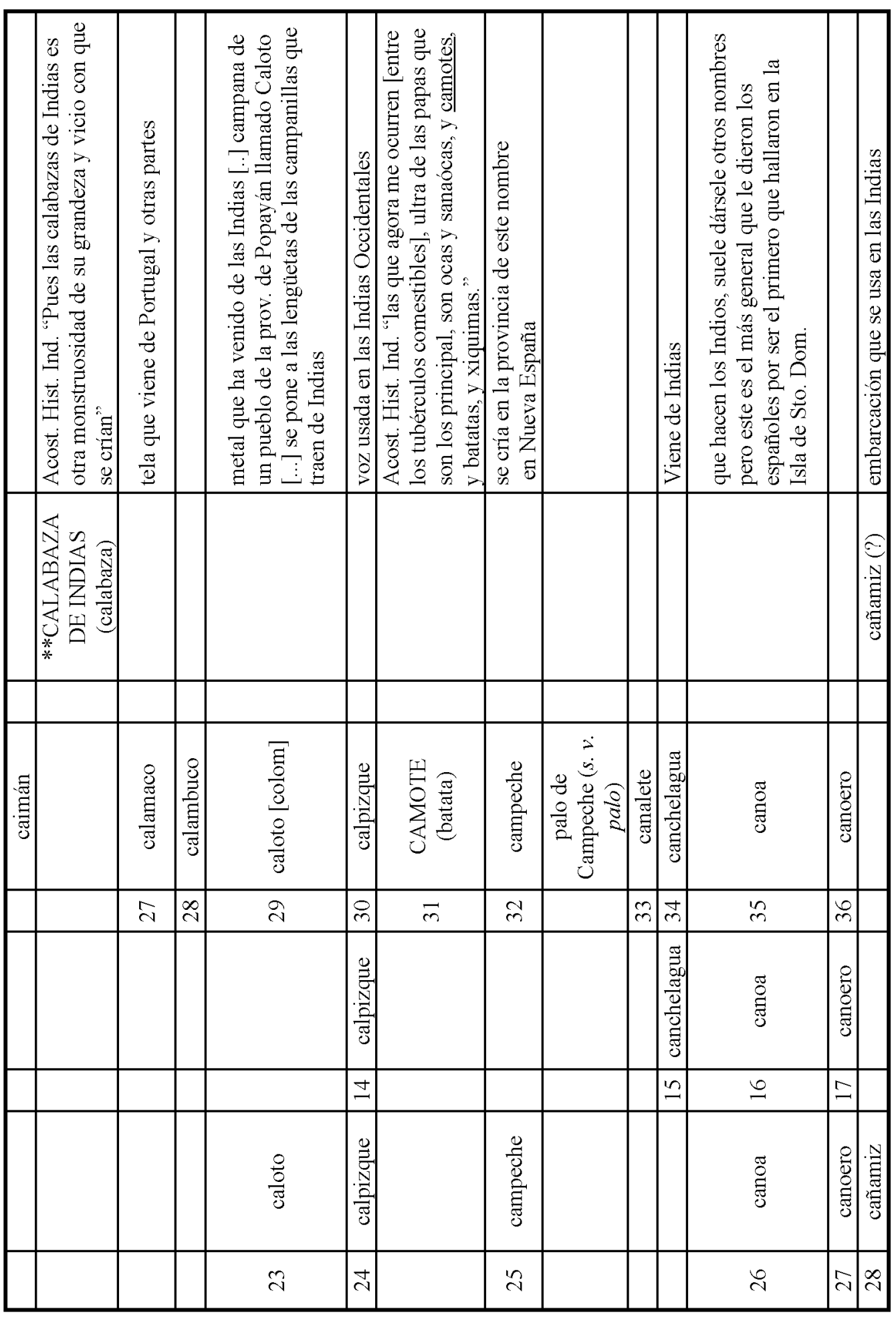




\begin{tabular}{|c|c|c|c|c|c|c|c|c|c|c|}
\hline 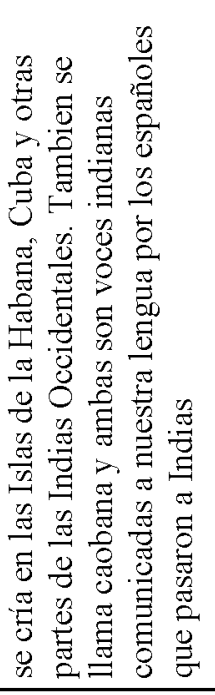 & 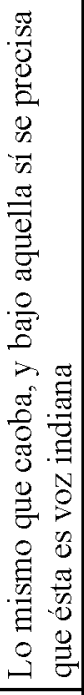 & 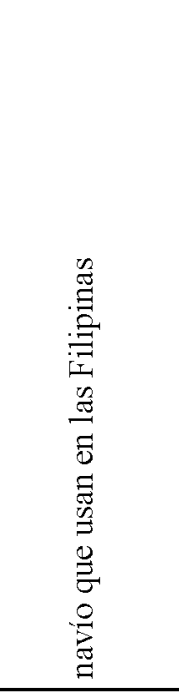 & 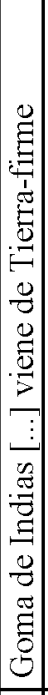 & & 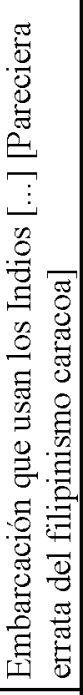 & 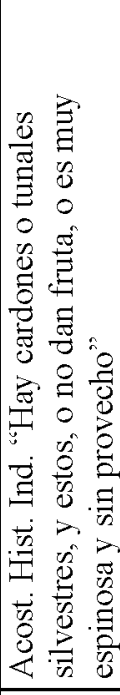 & 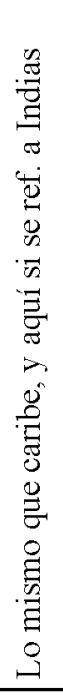 & 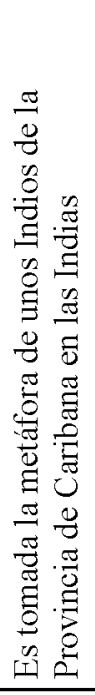 & 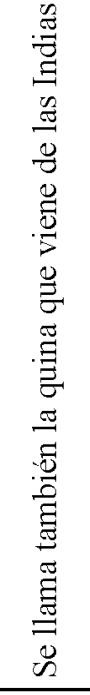 & 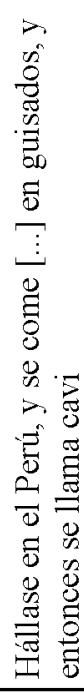 \\
\hline & & & & & & 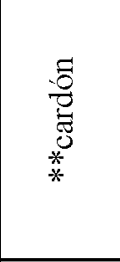 & & & 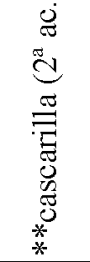 & \\
\hline $\begin{array}{l}\frac{\pi}{0} \\
\frac{8}{8} \\
0\end{array}$ & 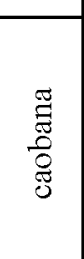 & & 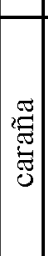 & 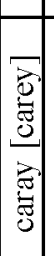 & & & 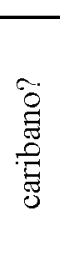 & $\frac{\mathscr{E}}{\mathbb{Z}}$ & & $\begin{array}{l}\overparen{8} \\
0 \\
\dot{0} \\
\dot{3} \\
\dot{0} \\
\dot{J}\end{array}$ \\
\hline$m$ & $\underset{m}{\infty}$ & & ले & ㅇ & & & ఫ & $\stackrel{\mathcal{F}}{\mathcal{H}}$ & & $\stackrel{g}{\forall}$ \\
\hline $\begin{array}{l}\frac{\pi}{0} \\
\frac{8}{8} \\
\end{array}$ & $\begin{array}{l}\widetilde{\Xi} \\
\tilde{\Xi} \\
\stackrel{0}{8} \\
\mathbb{J}\end{array}$ & 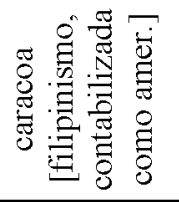 & 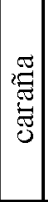 & & 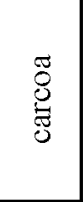 & & & & & 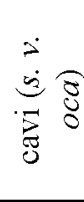 \\
\hline 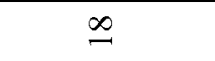 & 9 & & ণి & & $\vec{\sim}$ & & & & & 겅 \\
\hline $\begin{array}{l}\frac{\pi}{0} \\
0 \\
0 \\
0\end{array}$ & 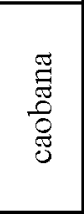 & & 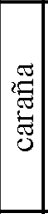 & & 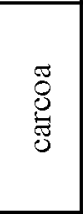 & & & $\frac{\mathscr{E}}{\bar{Z}}$ & 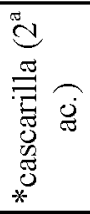 & 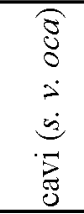 \\
\hline ते & ஜn & & $\bar{m}$ & & กี & & & 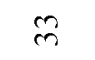 & I & $\Leftrightarrow$ \\
\hline
\end{tabular}




\begin{tabular}{|c|c|c|c|c|c|c|c|c|c|c|c|c|c|c|c|}
\hline 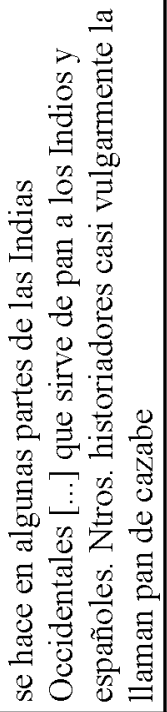 & & 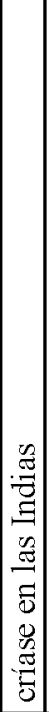 & & 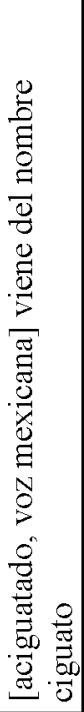 & 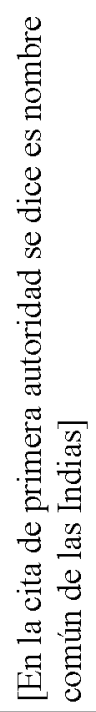 & & 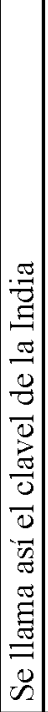 & 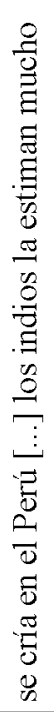 & 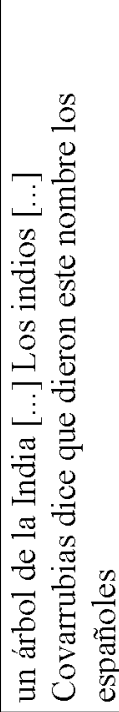 & 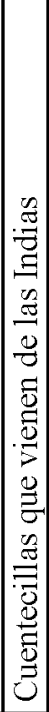 & 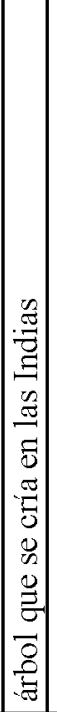 & 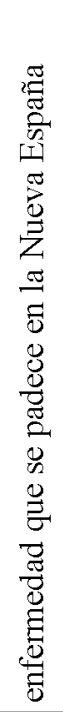 & 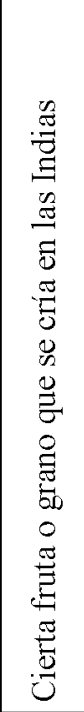 & & \\
\hline & & & & & 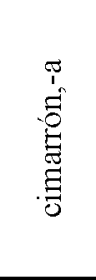 & 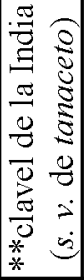 & 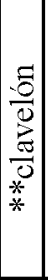 & & $\begin{array}{l}8 \\
8 \\
8\end{array}$ & $\begin{array}{l}2 \\
8 \\
8 \\
8\end{array}$ & $\mid \begin{array}{l}0 \\
8 \\
8 \\
8 \\
8 \\
8\end{array}$ & & 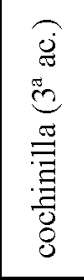 & 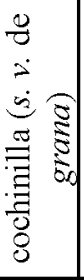 & \\
\hline & & & & & $a$ & & & & $\stackrel{\varrho}{ }$ & $=$ & 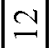 & & $\stackrel{m}{2}$ & & \\
\hline 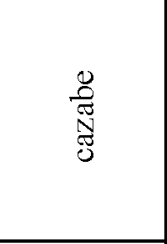 & 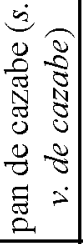 & 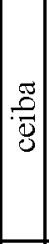 & 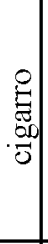 & 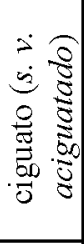 & & & & 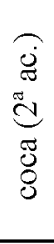 & & & & $\begin{array}{l}\frac{0}{n} \\
\frac{n}{8} \\
\frac{8}{8} \\
8\end{array}$ & & & \\
\hline 寸 & $\stackrel{10}{8}$ & $\underset{+}{0}$ & 于 & $\stackrel{\infty}{y}$ & & & & $\stackrel{g}{q}$ & & & & $i n$ & & & $\vec{n}$ \\
\hline 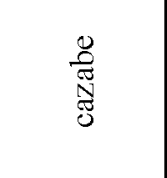 & & $\frac{\pi}{0}$ & & & & & & 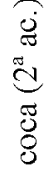 & 8 & & $\begin{array}{l}\frac{0}{8} \\
8 \\
8 \\
8 \\
8\end{array}$ & 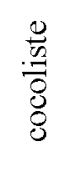 & & & \\
\hline$\ddot{\gamma}$ & & $\vec{\sim}$ & & & & & & $\stackrel{n}{n}$ & $\stackrel{\circ}{\sim}$ & & ㄱ. & $\stackrel{\infty}{\sim}$ & & & \\
\hline 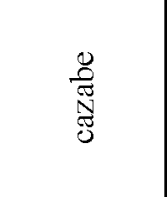 & & $\frac{\pi}{0}$ & & & $\begin{array}{l}\underset{T}{1} \\
\tilde{0} \\
\stackrel{0}{\Xi} \\
\stackrel{\Xi}{\Xi}\end{array}$ & & & 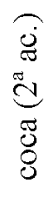 & $\begin{array}{l}8 \\
8\end{array}$ & $\begin{array}{l}8 \\
8 \\
8 \\
8\end{array}$ & $\mid \begin{array}{l}0 \\
8 \\
8 \\
8 \\
8 \\
8\end{array}$ & $\begin{array}{l}\frac{y}{0} \\
\frac{\pi}{8} \\
8 \\
8\end{array}$ & 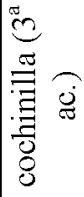 & & \\
\hline s & & $m$ & & & $\infty$ & & & ले & P & 于 & 于 & g & 寸 & & \\
\hline
\end{tabular}




\begin{tabular}{|c|c|c|c|c|c|c|c|c|c|c|c|c|c|c|}
\hline 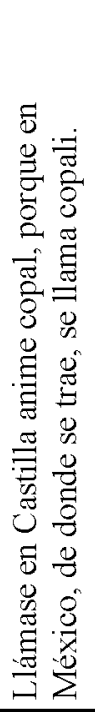 & 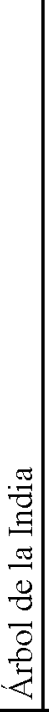 & 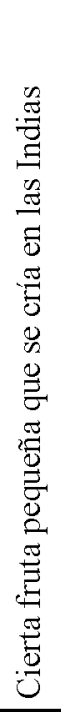 & 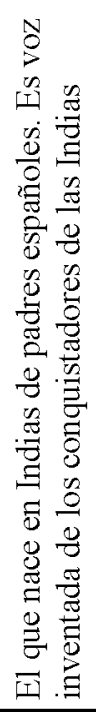 & 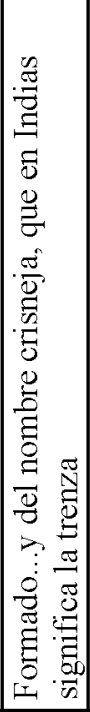 & 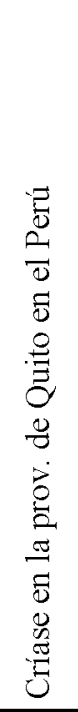 & 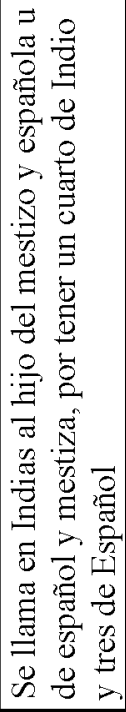 & 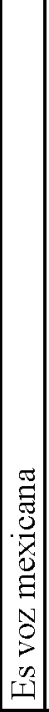 & 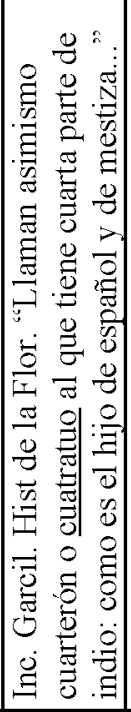 & 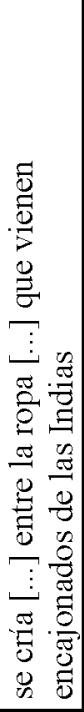 & 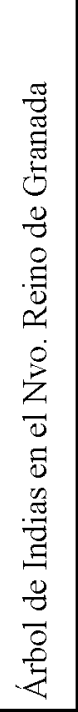 & 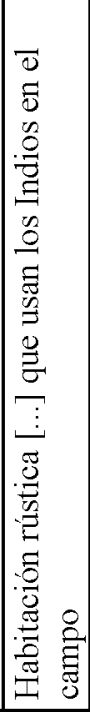 & 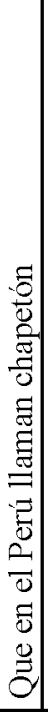 & 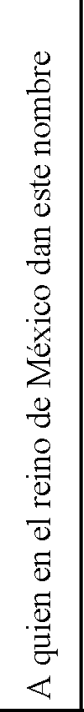 & 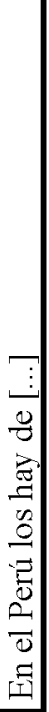 \\
\hline & & $\frac{\pi}{\stackrel{\pi}{\Xi}}$ & $\stackrel{\circ}{\stackrel{0}{0}}$ & 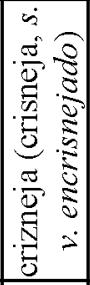 & & 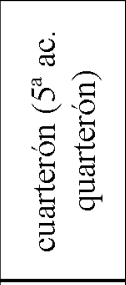 & & 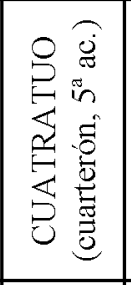 & 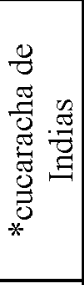 & & & 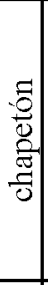 & 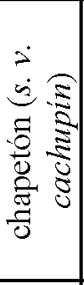 & \\
\hline & & 士 & $\stackrel{n}{2}$ & $\stackrel{0}{\bullet}$ & & 근 & & $\stackrel{\infty}{=}$ & & & & 2 & & \\
\hline 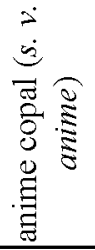 & 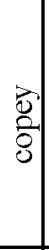 & & & & 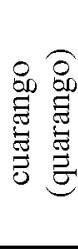 & & 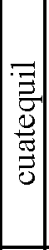 & & & 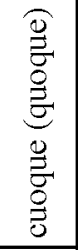 & $\begin{array}{l}\frac{\pi}{\tilde{J}} \\
\underset{\tilde{J}}{0}\end{array}$ & & & 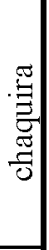 \\
\hline in & $\hat{n}$ & & & & in & & $i n$ & & & 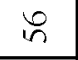 & in & & & $\infty$ \\
\hline & ऐ্ঠ & $\frac{\pi}{\frac{\pi}{3}}$ & & 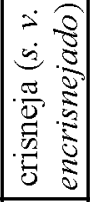 & 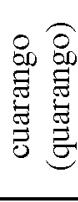 & 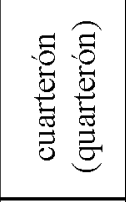 & 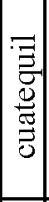 & & & 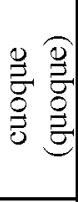 & & 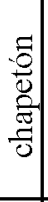 & 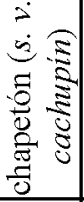 & \\
\hline & ते & 요 & & $\bar{m}$ & กิ & $m$ & ल) & & & $n$ & & D & & \\
\hline & 引े & & $\frac{\circ}{\frac{0}{0}}$ & & 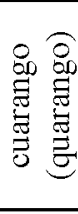 & 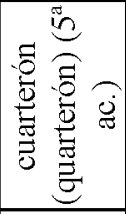 & 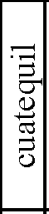 & & 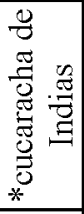 & 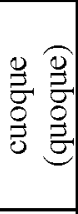 & & 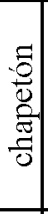 & & \\
\hline & $\stackrel{n}{8}$ & & f & & F & $\underset{+}{\infty}$ & $g$ & & 8 & $\bar{n}$ & & in & & \\
\hline
\end{tabular}




\begin{tabular}{|c|c|c|c|c|c|c|c|c|c|c|c|c|c|c|}
\hline 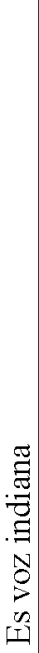 & 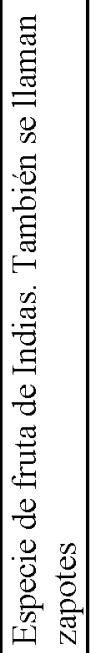 & & 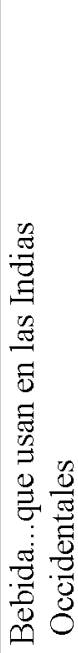 & & 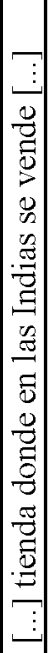 & & 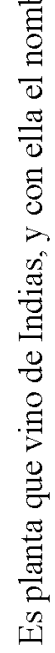 & 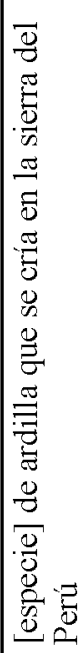 & 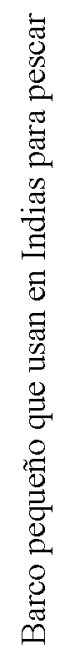 & 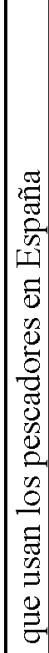 & 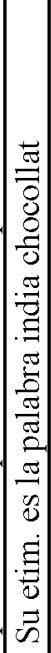 & & & \\
\hline & & & & & & & & & $\begin{array}{l}\stackrel{8}{0} \\
\frac{0}{0} \\
\stackrel{\Xi}{0}\end{array}$ & 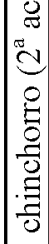 & & & & \\
\hline & & & & & & & & & 요 & $\vec{\sim}$ & & & & \\
\hline $\begin{array}{l}\exists \\
\vec{\Xi} \\
\frac{0}{0} \\
\bar{J}\end{array}$ & 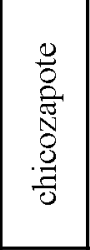 & 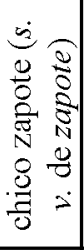 & $\frac{\overparen{7}}{0}$ & 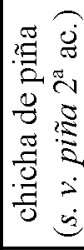 & 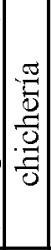 & 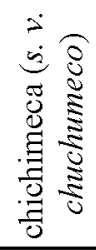 & 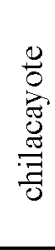 & 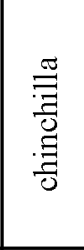 & & & 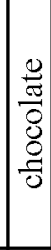 & 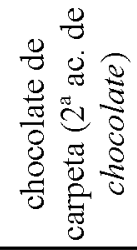 & 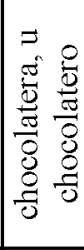 & 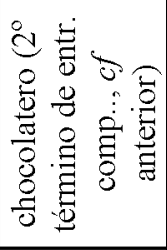 \\
\hline in & 8 & & $\bar{\sigma}$ & & ర్ర & $\ddot{b}$ & $\forall$ & 63 & & & 8 & & $\bar{\sigma}$ & 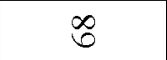 \\
\hline 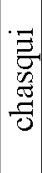 & & & $\begin{array}{l}\frac{\pi}{0} \\
\frac{0}{0}\end{array}$ & & & & 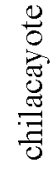 & & 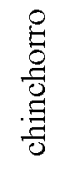 & & & & & \\
\hline $\bar{m}$ & & & $\stackrel{\infty}{m}$ & & & & $\stackrel{g}{m}$ & & \& & & & & & \\
\hline $\begin{array}{l}\exists \\
\overline{0} \\
\frac{0}{0} \\
\frac{\pi}{0}\end{array}$ & & & 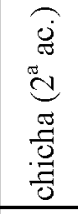 & & 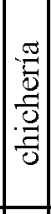 & & 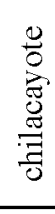 & 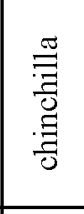 & 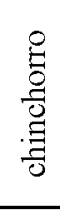 & & 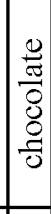 & & & \\
\hline$\hat{n}$ & & & in & & in & & $\stackrel{0}{n}$ & in & $\stackrel{\infty}{\infty}$ & & in & & & \\
\hline
\end{tabular}




\begin{tabular}{|c|c|c|c|c|c|c|c|c|c|c|c|c|c|c|c|}
\hline & 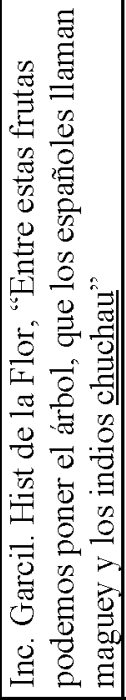 & 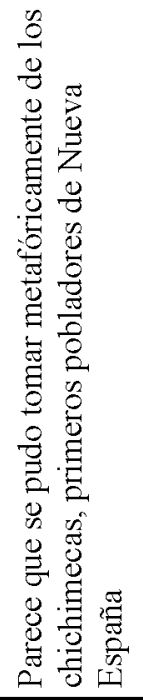 & 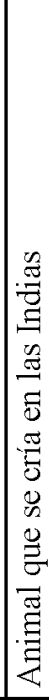 & 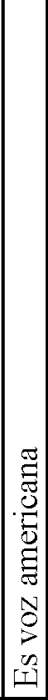 & 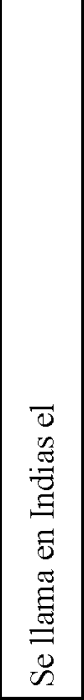 & 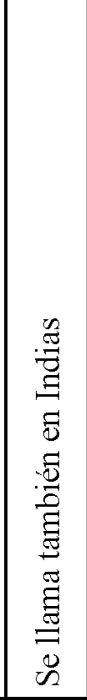 & 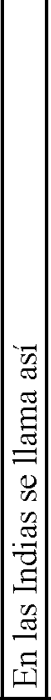 & & 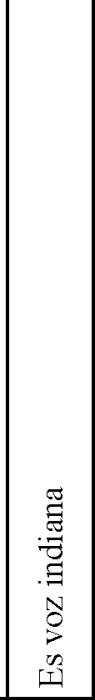 & & 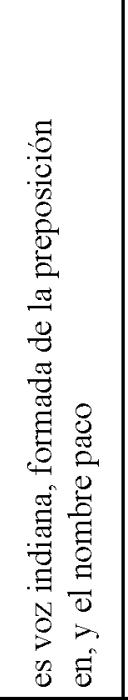 & & & & 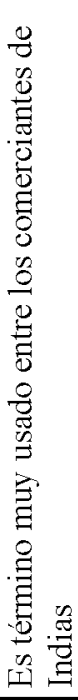 \\
\hline & & & 丞 & & 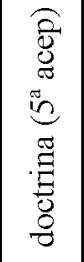 & 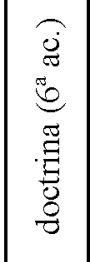 & 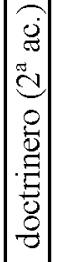 & & & & & & & & 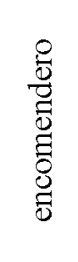 \\
\hline & & & 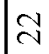 & & $\ddot{\sim}$ & U & $\approx$ & & & & & & & & $\stackrel{\bullet}{\sim}$ \\
\hline $\begin{array}{l}0 \\
\frac{0}{2} \\
\frac{\pi}{8} \\
8 \\
\frac{8}{0}\end{array}$ & 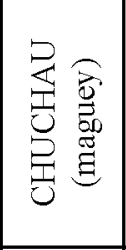 & 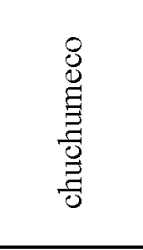 & & $\begin{array}{l}0 \\
2 \\
0 \\
0 \\
0 \\
\vdots \\
\vdots \\
0 \\
0 \\
0 \\
0\end{array}$ & & & & 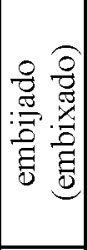 & 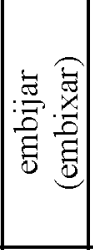 & 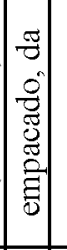 & 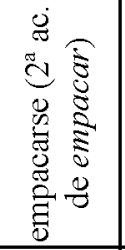 & 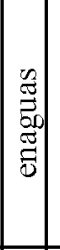 & 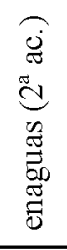 & 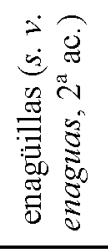 & \\
\hline \multirow[t]{5}{*}{6} & P & $\nabla$ & & $N$ & & & & $\stackrel{m}{r}$ & $\stackrel{N}{N}$ & 12 & $\stackrel{6}{1}$ & $\therefore$ & & & \\
\hline & & & 莺 & & 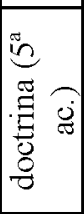 & 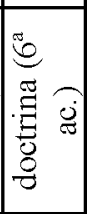 & & & 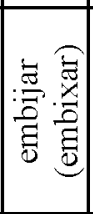 & & 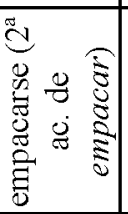 & & & & 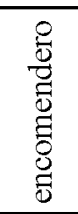 \\
\hline & & & 寸 & & $\stackrel{\mathcal{F}}{\mathcal{O}}$ & $\stackrel{m}{q}$ & & & 寸 & & in & & & & o \\
\hline & & & 苂 & \begin{tabular}{|l|} 
\\
0 \\
0 \\
0 \\
0 \\
0 \\
0 \\
0 \\
0 \\
0 \\
0 \\
0 \\
0 \\
\end{tabular} & $\frac{\mathscr{\Xi}}{\stackrel{\Xi}{\Xi}}$ & & 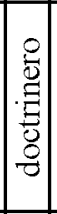 & 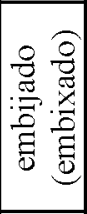 & 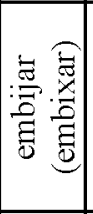 & & 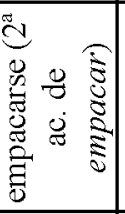 & & & & 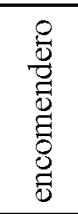 \\
\hline & & & 8 & 6 & ชె & & $\hat{b}$ & t & 6 & & 8 & & & & $\hat{\sigma}$ \\
\hline
\end{tabular}




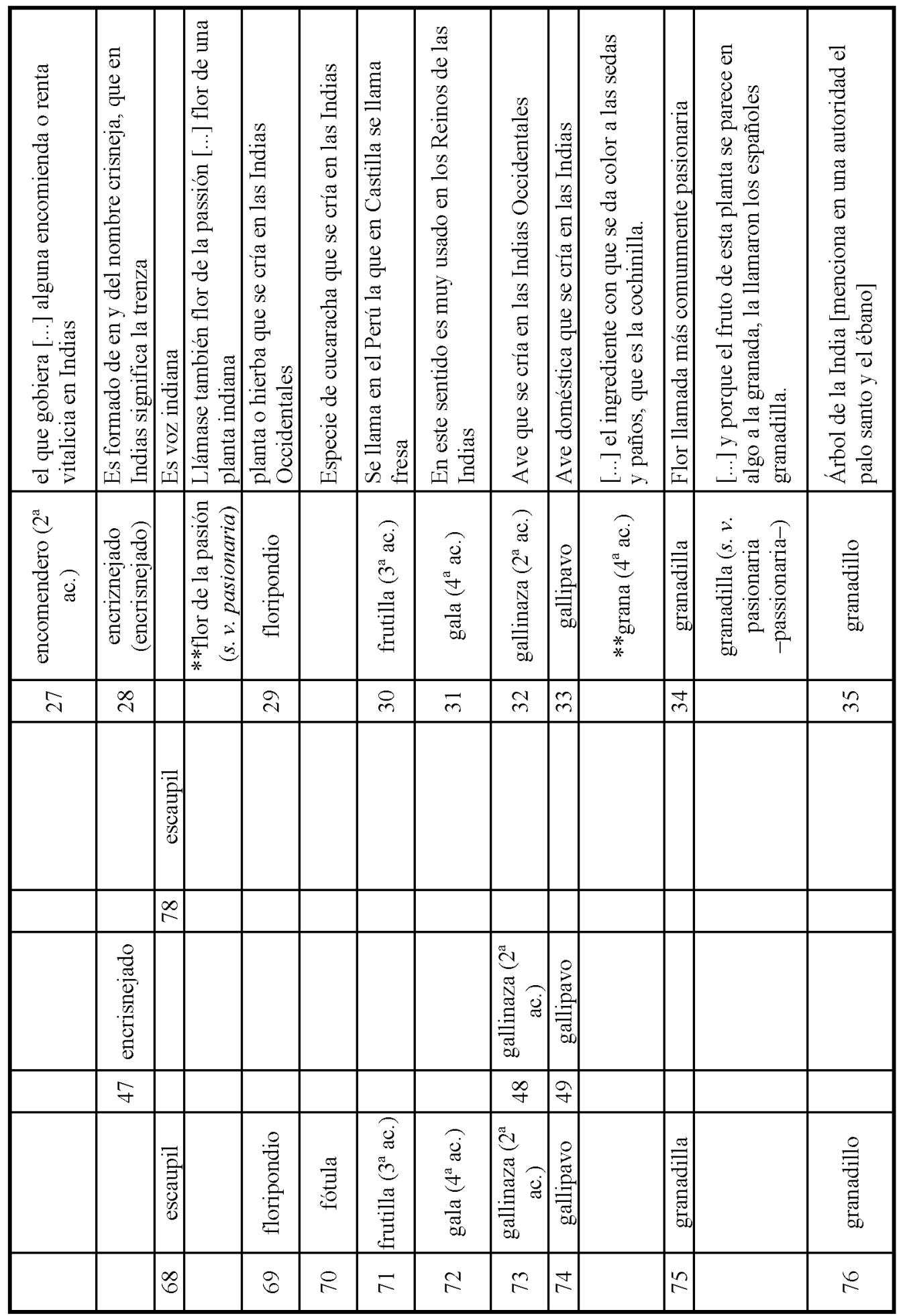




\begin{tabular}{|c|c|c|c|c|c|c|c|c|c|c|c|c|}
\hline & & 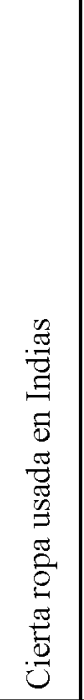 & 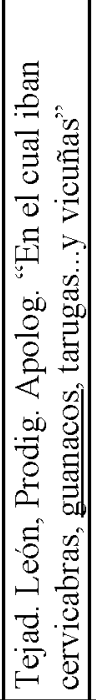 & 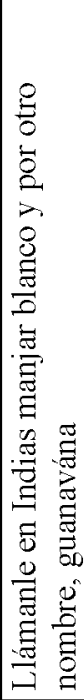 & 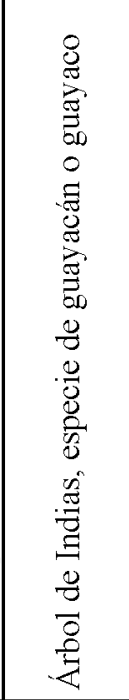 & 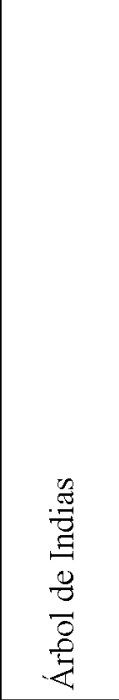 & & 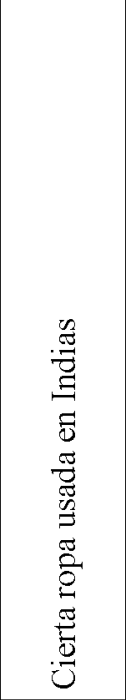 & 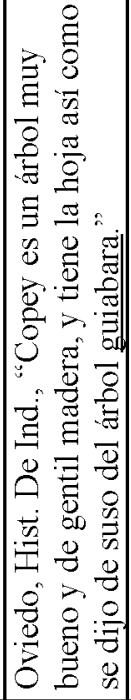 & 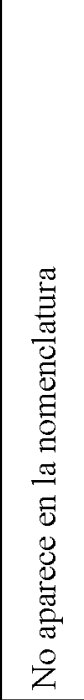 & 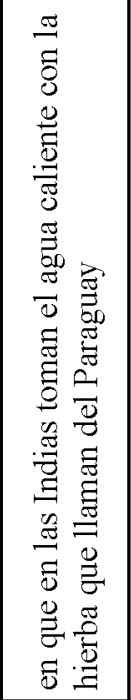 & \\
\hline & & & & & & & & & & & 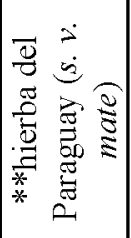 & 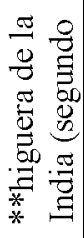 \\
\hline & & & & & & & & & & & on & \\
\hline 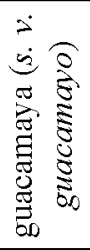 & 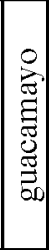 & 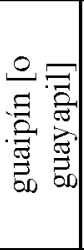 & 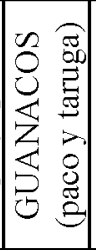 & 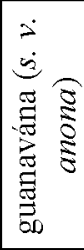 & 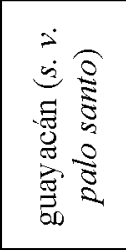 & 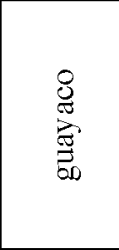 & 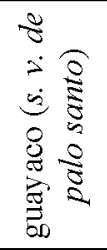 & 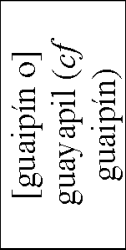 & 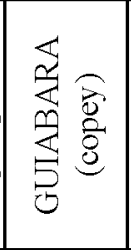 & 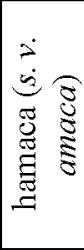 & & \\
\hline 2 & 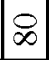 & $\vec{\infty}$ & $\infty$ & $\ddot{\infty}$ & $\underset{\infty}{ }$ & $\infty$ & & $\infty$ & $\bar{\infty}$ & & & \\
\hline & & 寻 & & 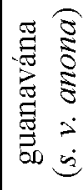 & & 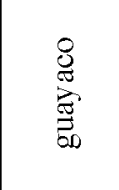 & & 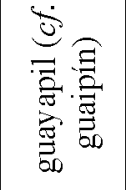 & & & & \\
\hline & & in & & $\bar{n}$ & & in & & $\ddot{n}$ & & & & \\
\hline & & & & 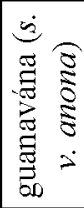 & 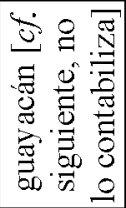 & 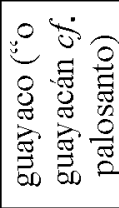 & & & & & & \\
\hline & & & & $\hat{r}$ & $\stackrel{\infty}{\sim}$ & 2 & & & & & & \\
\hline
\end{tabular}




\begin{tabular}{|c|c|c|c|c|c|c|c|c|c|c|c|c|}
\hline & 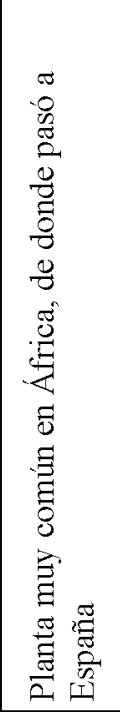 & 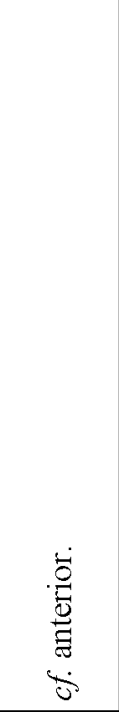 & 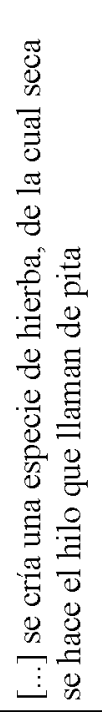 & & 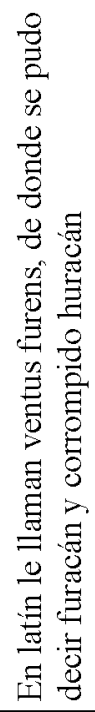 & 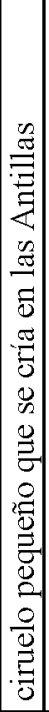 & 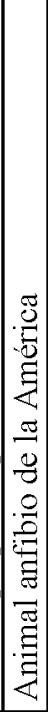 & 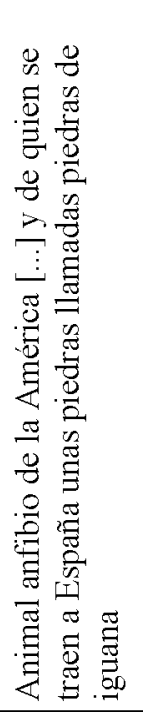 & 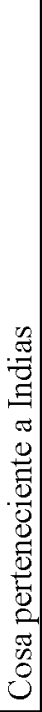 & 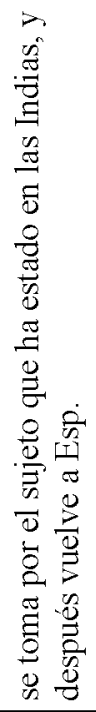 & 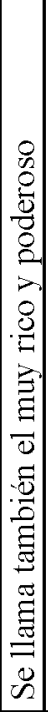 & 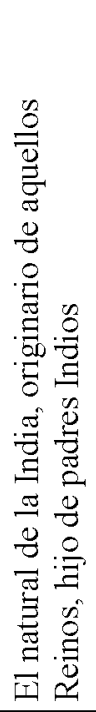 \\
\hline 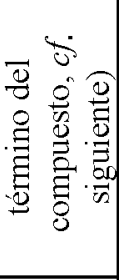 & 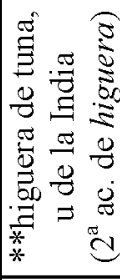 & 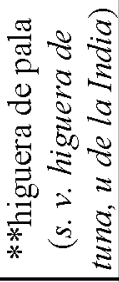 & 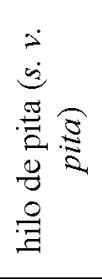 & & & & & & 忐 & 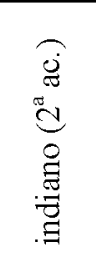 & 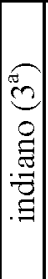 & 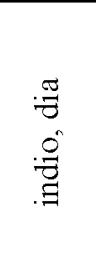 \\
\hline & n & & $\stackrel{\infty}{m}$ & & & & & & & & & \\
\hline & & & & $\stackrel{\stackrel{0}{\Xi}}{\Xi}$ & 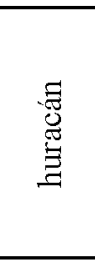 & $\begin{array}{l}0 \\
.0 \\
.0 \\
.0\end{array}$ & 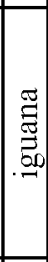 & 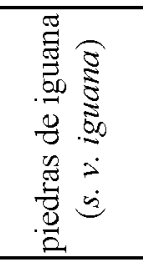 & & & & \\
\hline & & & & $\infty$ & 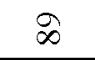 & ஓ & $\bar{a}$ & ๙ & & & & \\
\hline & & & & & & 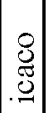 & 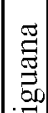 & & & & & \\
\hline & & & & & & in & in & & & & & \\
\hline & & & & & &. & 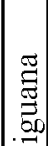 & & & & & \\
\hline & & & & & & $\infty$ & $\bar{\infty}$ & & & & & \\
\hline
\end{tabular}




\begin{tabular}{|c|c|c|c|c|c|c|c|c|c|c|c|c|}
\hline 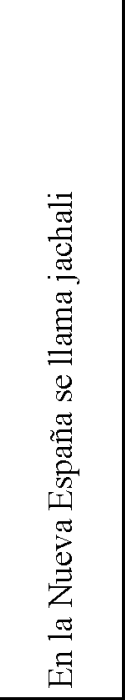 & 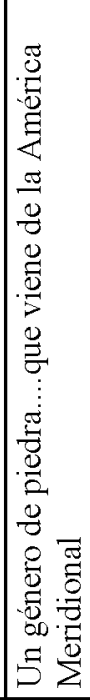 & 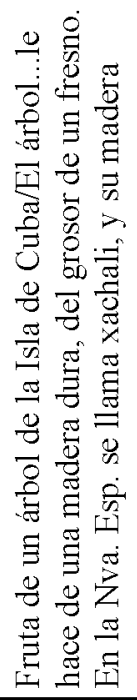 & 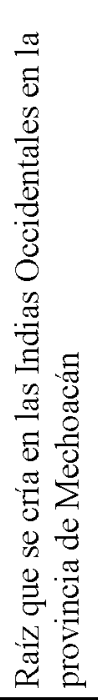 & 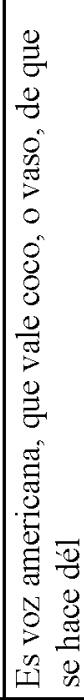 & 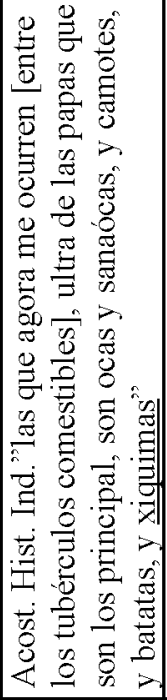 & 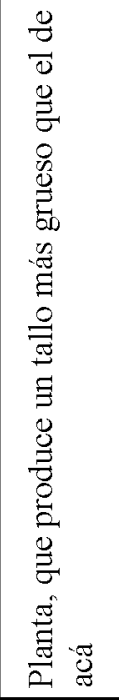 & 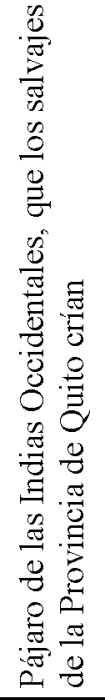 & 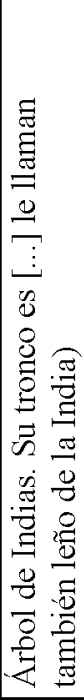 & 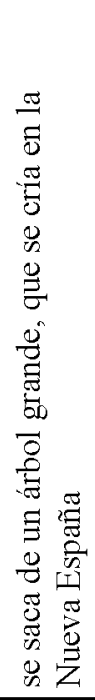 & 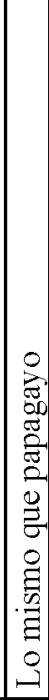 & 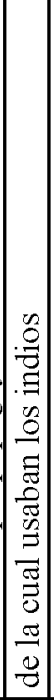 & 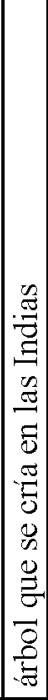 \\
\hline & $\frac{\mathbb{v}}{\mathbb{\sigma}}$ & & & & & & & 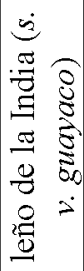 & 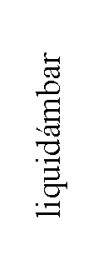 & & & \\
\hline & ले & & & & & & & \& & $\exists$ & & & \\
\hline 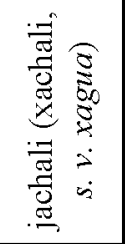 & & 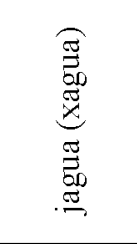 & 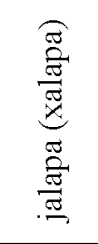 & 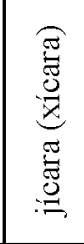 & 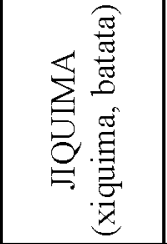 & & 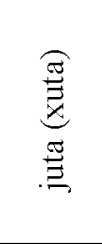 & & & : & 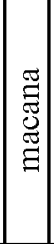 & 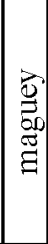 \\
\hline$\hat{\sigma}$ & & $\Xi$ & $\mathfrak{\alpha}$ & 2 & 5 & & $\stackrel{\infty}{\sigma}$ & & & হ & 8 & 0 \\
\hline 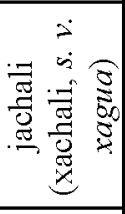 & & 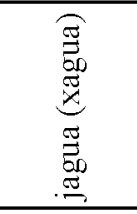 & & 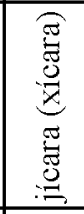 & & & 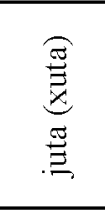 & & & & $\begin{array}{c}\underset{\Xi}{\Xi} \\
\stackrel{\Xi}{\Xi} \\
\stackrel{\Xi}{\Xi}\end{array}$ & 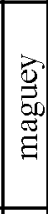 \\
\hline in & & in & & $\infty$ & & & in & & & & 8 & 6 \\
\hline 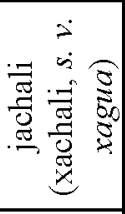 & & 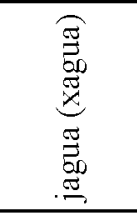 & 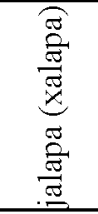 & 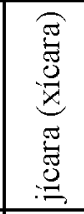 & & * & 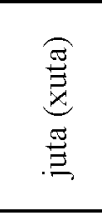 & & 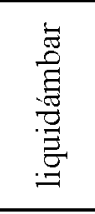 & & 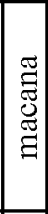 & $\mid \begin{array}{l}3 \\
0 \\
0 \\
0 \\
0 \\
0 \\
0\end{array}$ \\
\hline $\bar{\infty}$ & & $\infty$ & 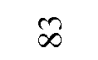 & $\underset{\infty}{+}$ & & $\infty$ & $\infty$ & & $\hat{\infty}$ & & $\infty$ & $\infty$ \\
\hline
\end{tabular}




\begin{tabular}{|c|c|c|c|c|c|c|c|c|c|c|c|}
\hline & & 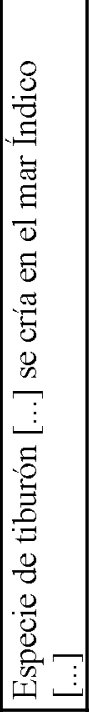 & 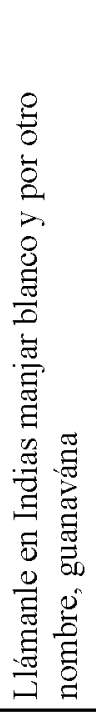 & 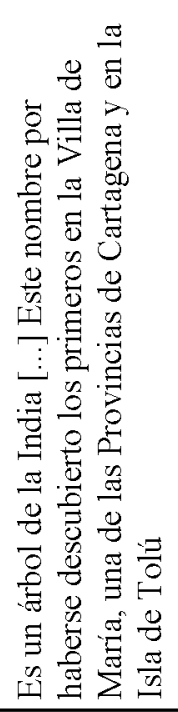 & 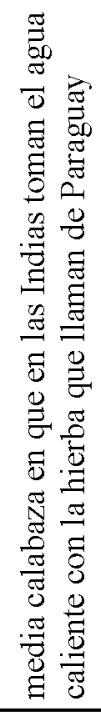 & & 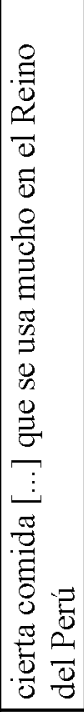 & 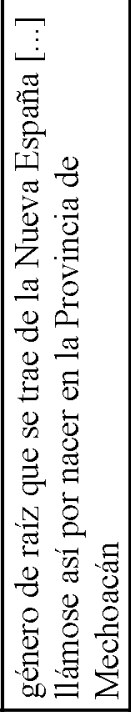 & & 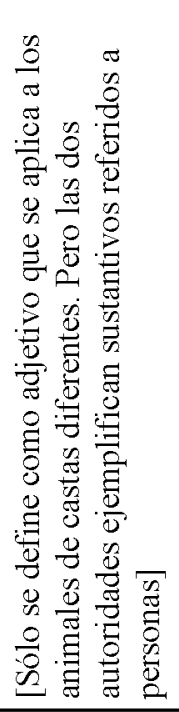 & 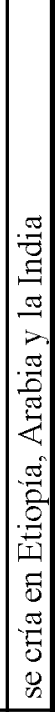 \\
\hline & & & 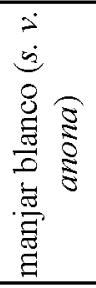 & 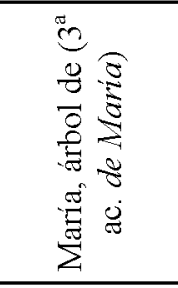 & & & 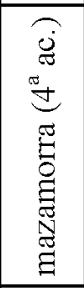 & & & 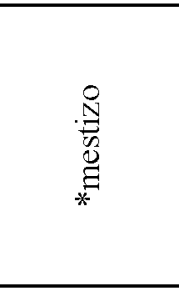 & \\
\hline & & & $\stackrel{\sim}{\forall}$ & $\stackrel{m}{\vartheta}$ & & & $\underset{\forall}{\forall}$ & & & & \\
\hline 콬. & 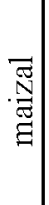 & 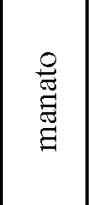 & & & 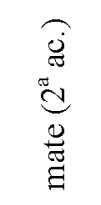 & 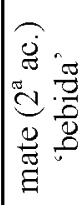 & & 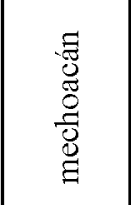 & & & $\stackrel{\circ}{\Xi}$ \\
\hline \multirow[t]{5}{*}{ 8ิ } & $\stackrel{8}{0}$ & 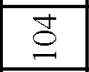 & & & 8 & & & $\stackrel{8}{8}$ & & & 5 \\
\hline & & & 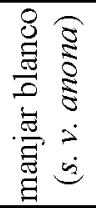 & 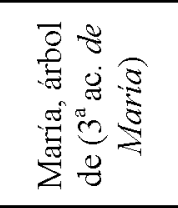 & 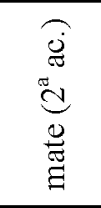 & & 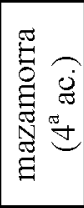 & & & & \\
\hline & & & $\widehat{\vartheta}$ & $\hat{b}$ & $\mathbb{J}$ & & 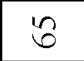 & & & & \\
\hline & & & 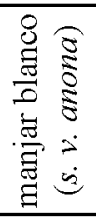 & 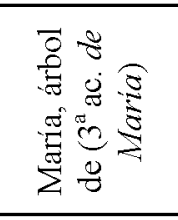 & 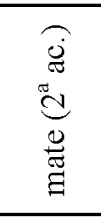 & & 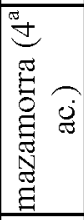 & $\begin{array}{l}\tilde{\Xi} \\
\stackrel{8}{8} \\
\stackrel{8}{8} \\
\stackrel{\Xi}{\Xi}\end{array}$ & 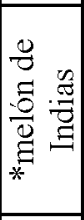 & & \\
\hline & & & § & $\bar{a}$ & నু & & 2 & J & 2 & & \\
\hline
\end{tabular}




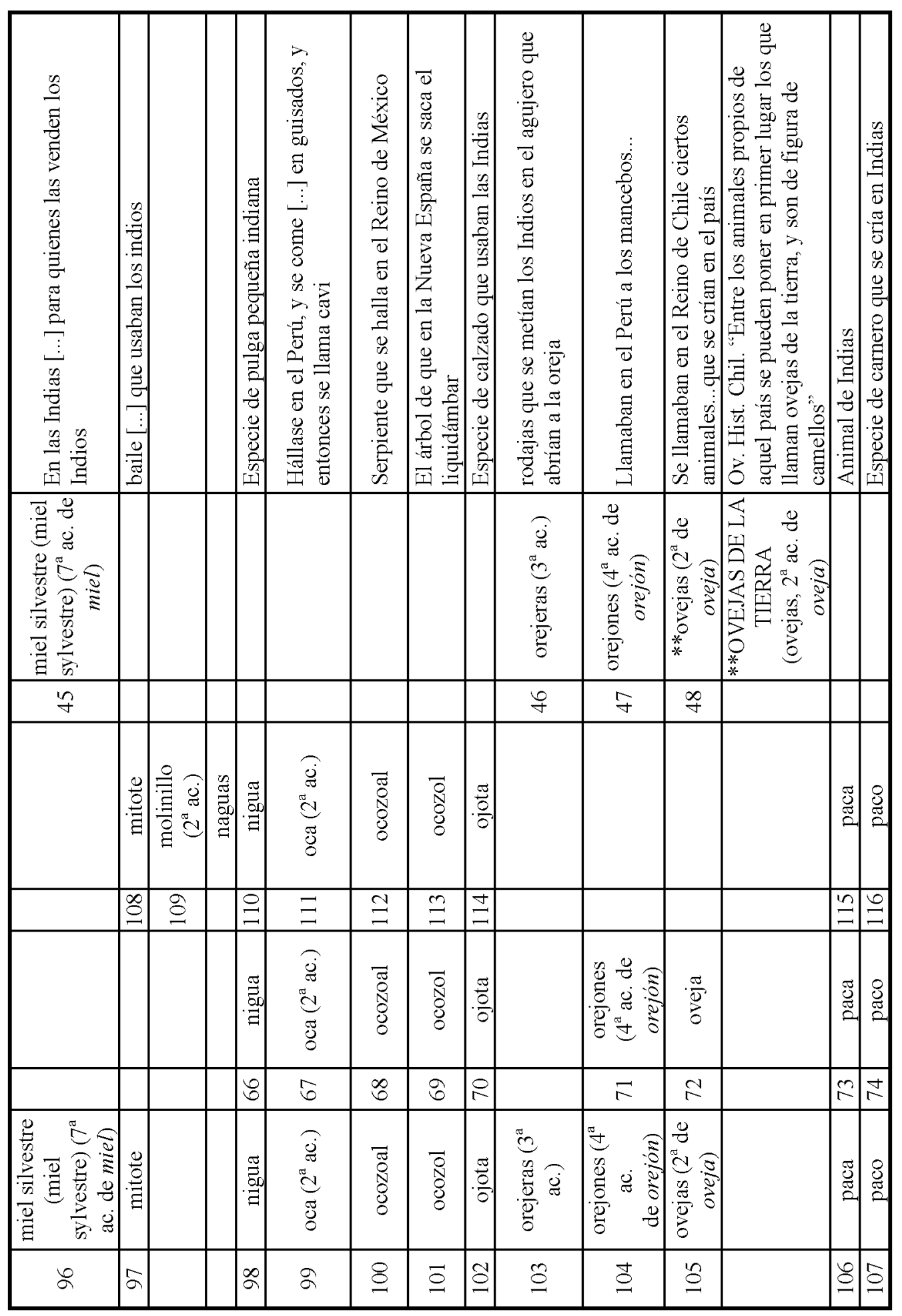




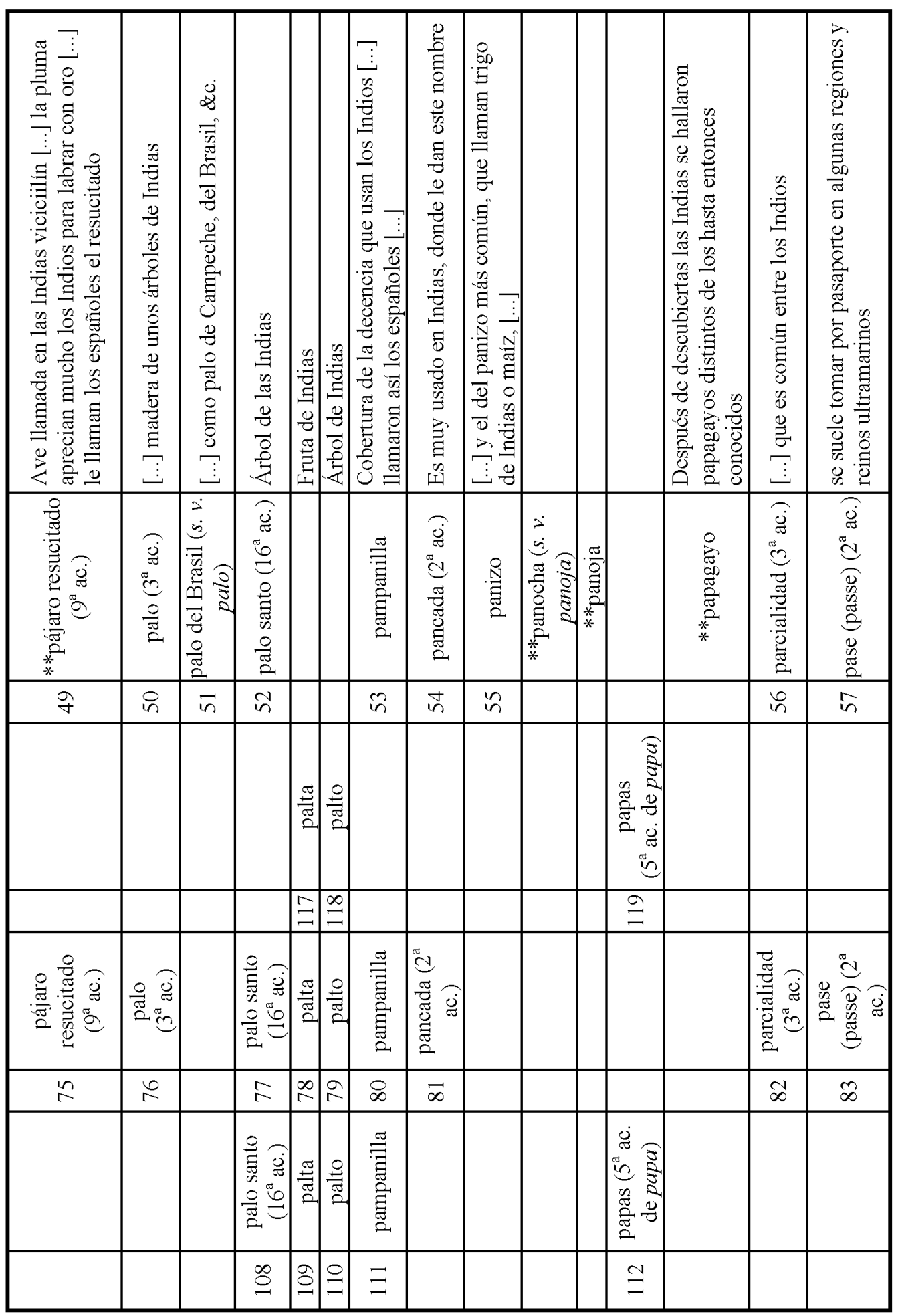




\begin{tabular}{|c|c|c|c|c|c|c|c|c|c|c|c|c|c|c|c|}
\hline 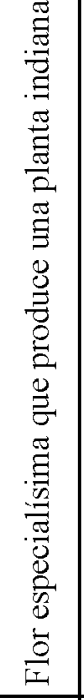 & 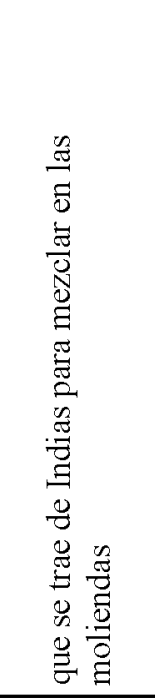 & & & 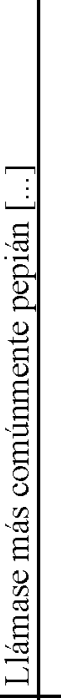 & 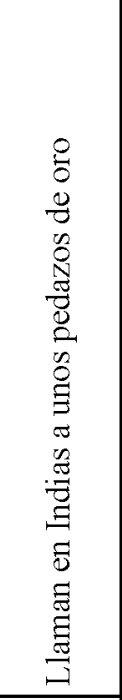 & 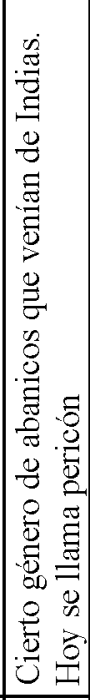 & & 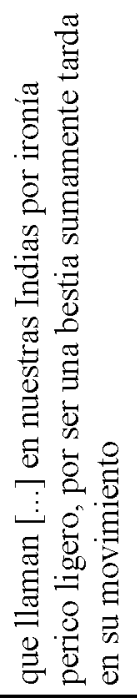 & 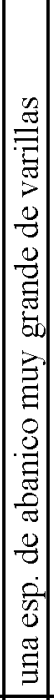 & 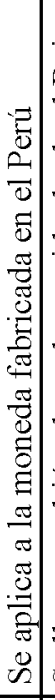 & 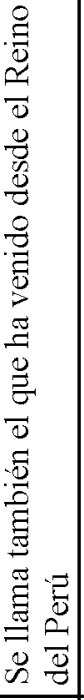 & 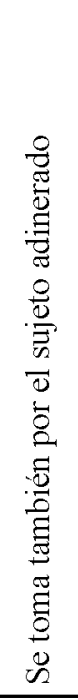 & & & 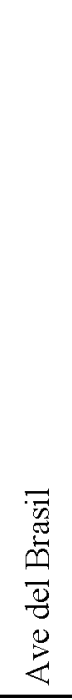 \\
\hline 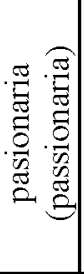 & 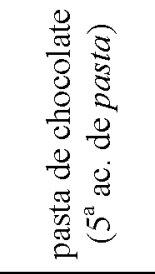 & & : & 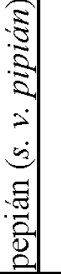 & 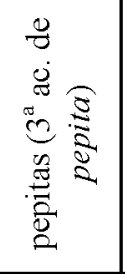 & 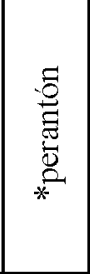 & 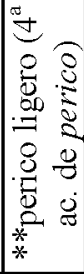 & 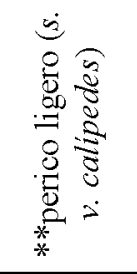 & 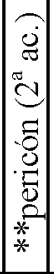 & & & & & & \\
\hline$\stackrel{\infty}{n}$ & & & in & & 8 & & & $\bar{\sigma}$ & & & & & & & \\
\hline & & 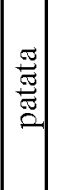 & & & & & & & & 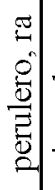 & 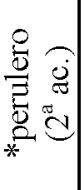 & 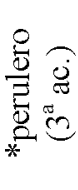 & 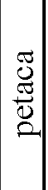 & 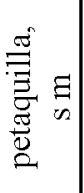 & $\begin{array}{l}0 \\
0 \\
0 \\
0 \\
0 \\
0 \\
0 \\
0 \\
0 \\
0\end{array}$ \\
\hline & & ণิ & & & & & & & & $\vec{\beth}$ & & & I & & $\stackrel{3}{\mathcal{C}}$ \\
\hline & & & & & 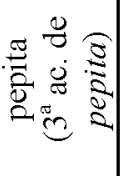 & & & & & & & & & & 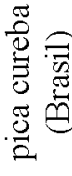 \\
\hline & & & & & $\Phi$ & & & & & & & & & & $\stackrel{n}{\infty}$ \\
\hline 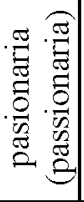 & 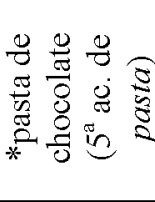 & & & & 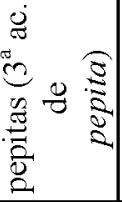 & 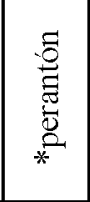 & & & & & & & & & \\
\hline$\stackrel{9}{\Xi}$ & 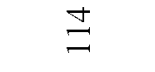 & & & & $\stackrel{10}{=}$ & $\stackrel{\varrho}{=}$ & & & & & & & & & \\
\hline
\end{tabular}




\begin{tabular}{|c|c|c|c|c|c|c|c|c|c|}
\hline 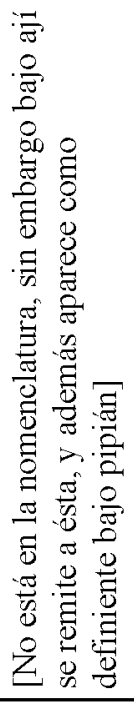 & & 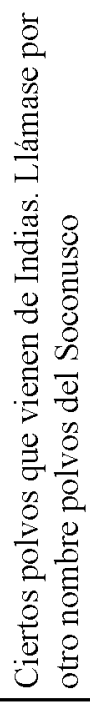 & 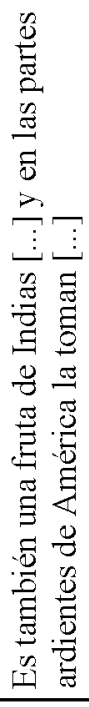 & 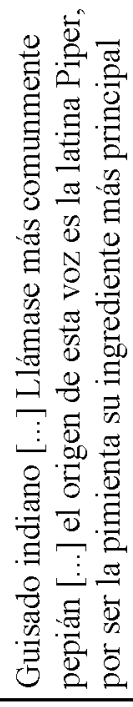 & 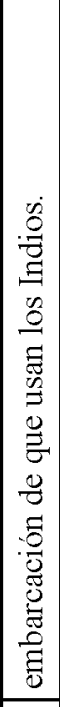 & 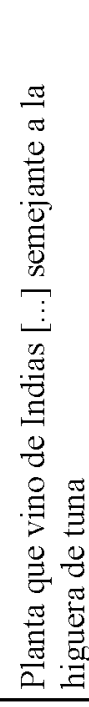 & 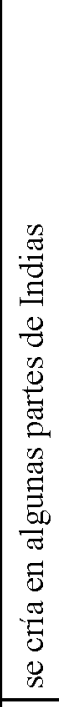 & & \\
\hline 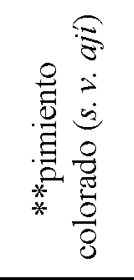 & 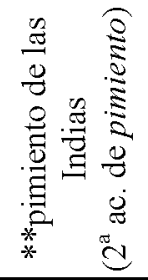 & & 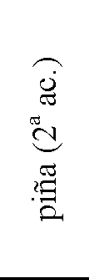 & 痣 & & & 量 & 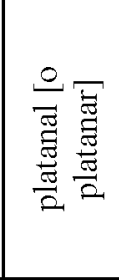 & 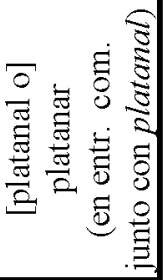 \\
\hline 6 & & & 3 & t & & & 13 & 8 & 6 \\
\hline & & $\begin{array}{l}\frac{0}{0} \\
\stackrel{\Xi}{0}\end{array}$ & & & 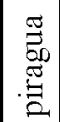 & 营 & & & \\
\hline & & $\underset{J}{J}$ & & & $\stackrel{1}{a}$ & $\stackrel{\text { I }}{\text { I }}$ & & & \\
\hline & & $\frac{\stackrel{0}{0}}{\Xi}$ & 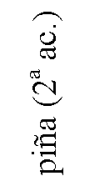 & & 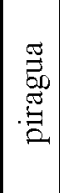 & & & & \\
\hline & & 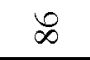 & $\hat{\infty}$ & & $\infty$ & & & & \\
\hline & 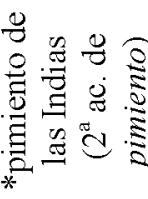 & $\begin{array}{l}\frac{\vartheta}{0} \\
\stackrel{\Xi}{\Xi}\end{array}$ & 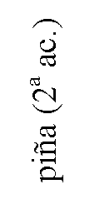 & 犈 & 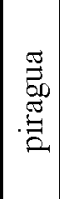 & 苟 & : & 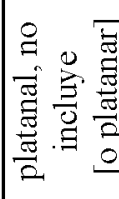 & \\
\hline & $\Xi$ & $\stackrel{\infty}{=}$ & $\stackrel{\varrho}{\Xi}$ & $\bar{\Xi}$ & $\underset{త}{\Xi}$ & $\stackrel{3}{3}$ & $\stackrel{\Xi}{\leftrightarrows}$ & $\stackrel{12}{3}$ & \\
\hline
\end{tabular}




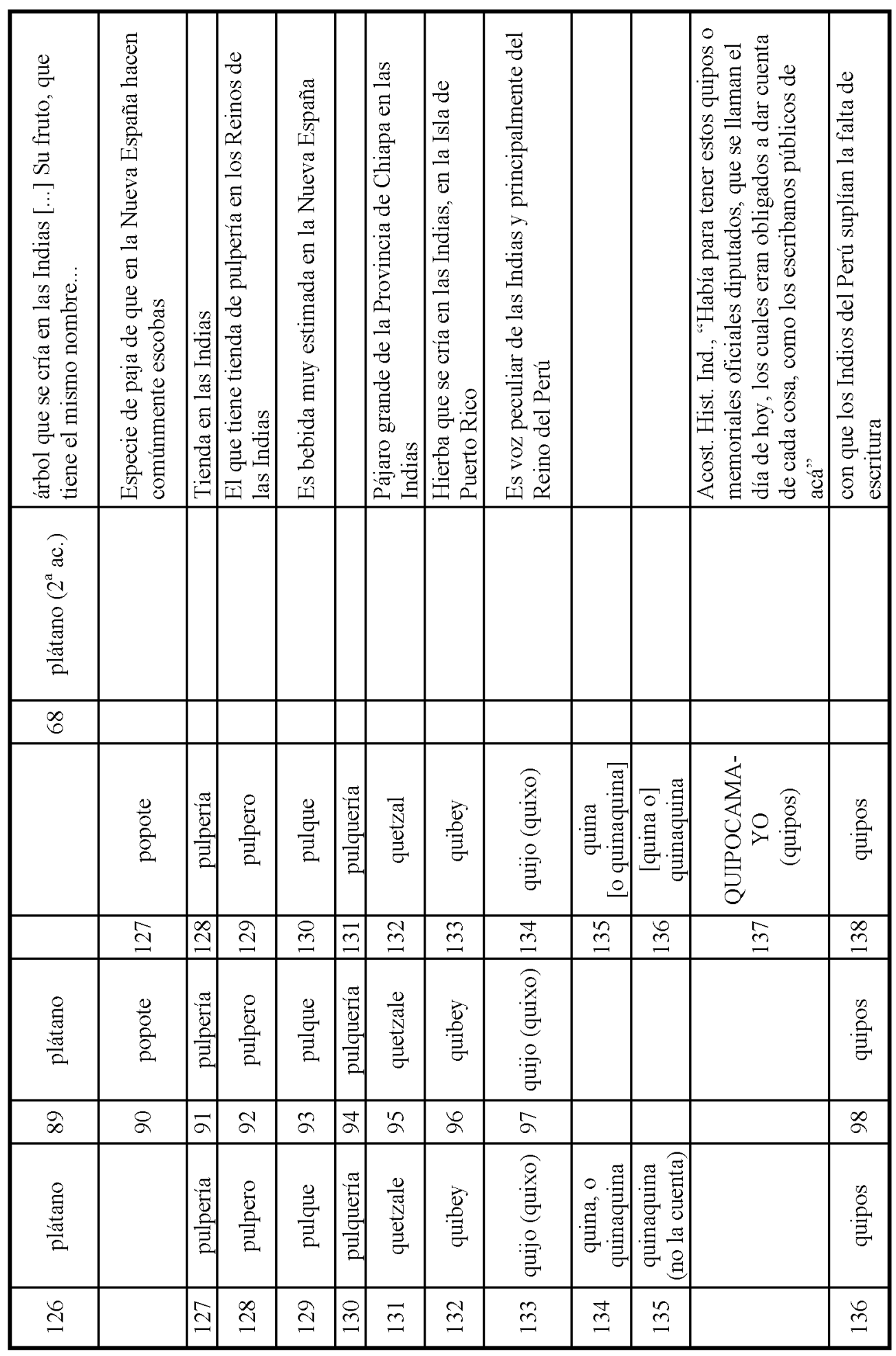




\begin{tabular}{|c|c|c|c|c|c|c|c|c|c|c|c|c|c|}
\hline 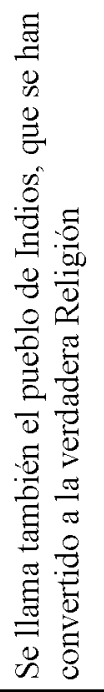 & & 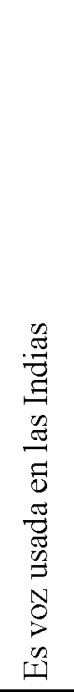 & & 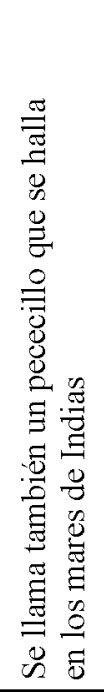 & 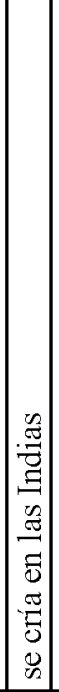 & 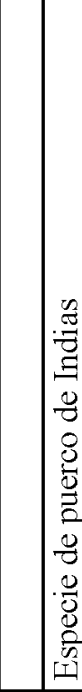 & 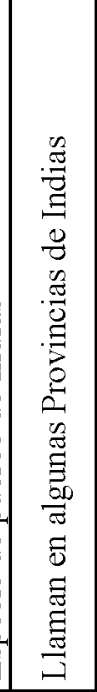 & 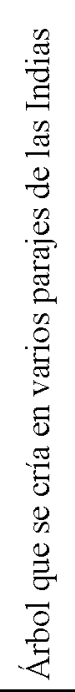 & 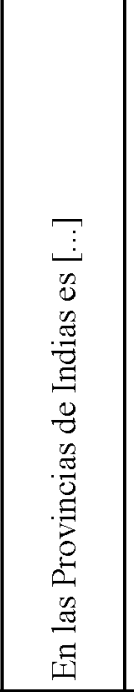 & 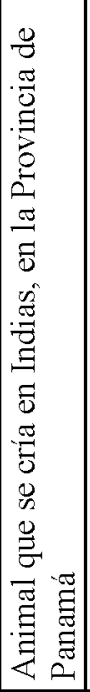 & & & 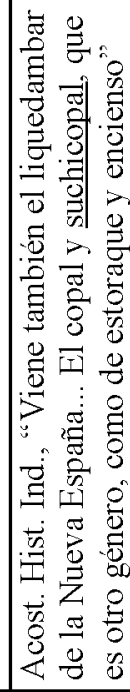 \\
\hline 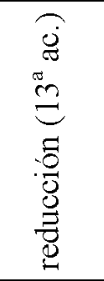 & 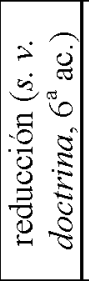 & 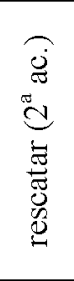 & 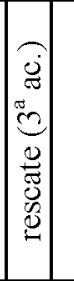 & 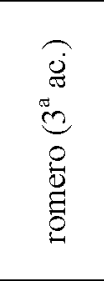 & & & 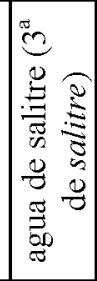 & & 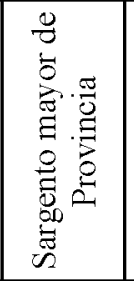 & 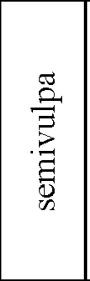 & & & \\
\hline 8 & & 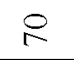 & $\pi$ & $\frac{n}{4}$ & & & $m$ & & 吉 & $\stackrel{12}{r}$ & & & \\
\hline & & & & & & 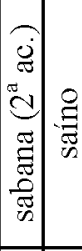 & & & & & 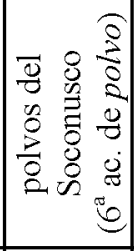 & 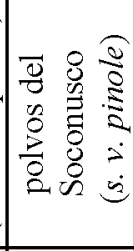 & 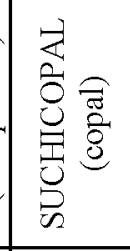 \\
\hline & & & & & & 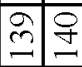 & & & & & $\vec{\exists}$ & & 等 \\
\hline 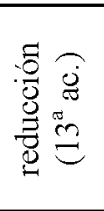 & & 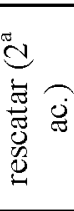 & & 总 & & & 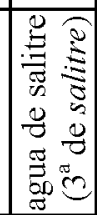 & & & 莺 & & 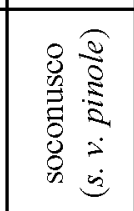 & \\
\hline 2 & & 8 & & 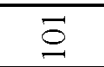 & & & $\delta$ & & & $\hat{\varrho}$ & & $\stackrel{+}{0}$ & \\
\hline 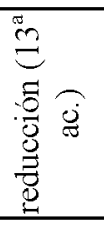 & & 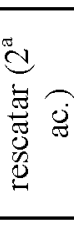 & & $\stackrel{\substack{0 \\
0}}{\stackrel{0}{0}}$ & 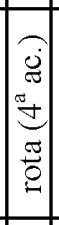 & $\stackrel{g}{\sharp}$ & 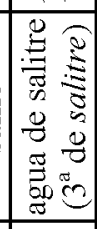 & 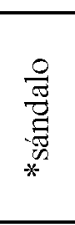 & 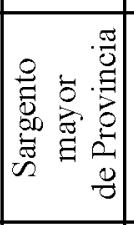 & 莺 & & & \\
\hline 흔 & & $\stackrel{\infty}{\stackrel{\infty}{\sim}}$ & & $\stackrel{\text { }}{2}$ & 용 & 寻 & I & $\stackrel{g}{I}$ & 寻 & $\stackrel{\text { In }}{=}$ & & & \\
\hline
\end{tabular}




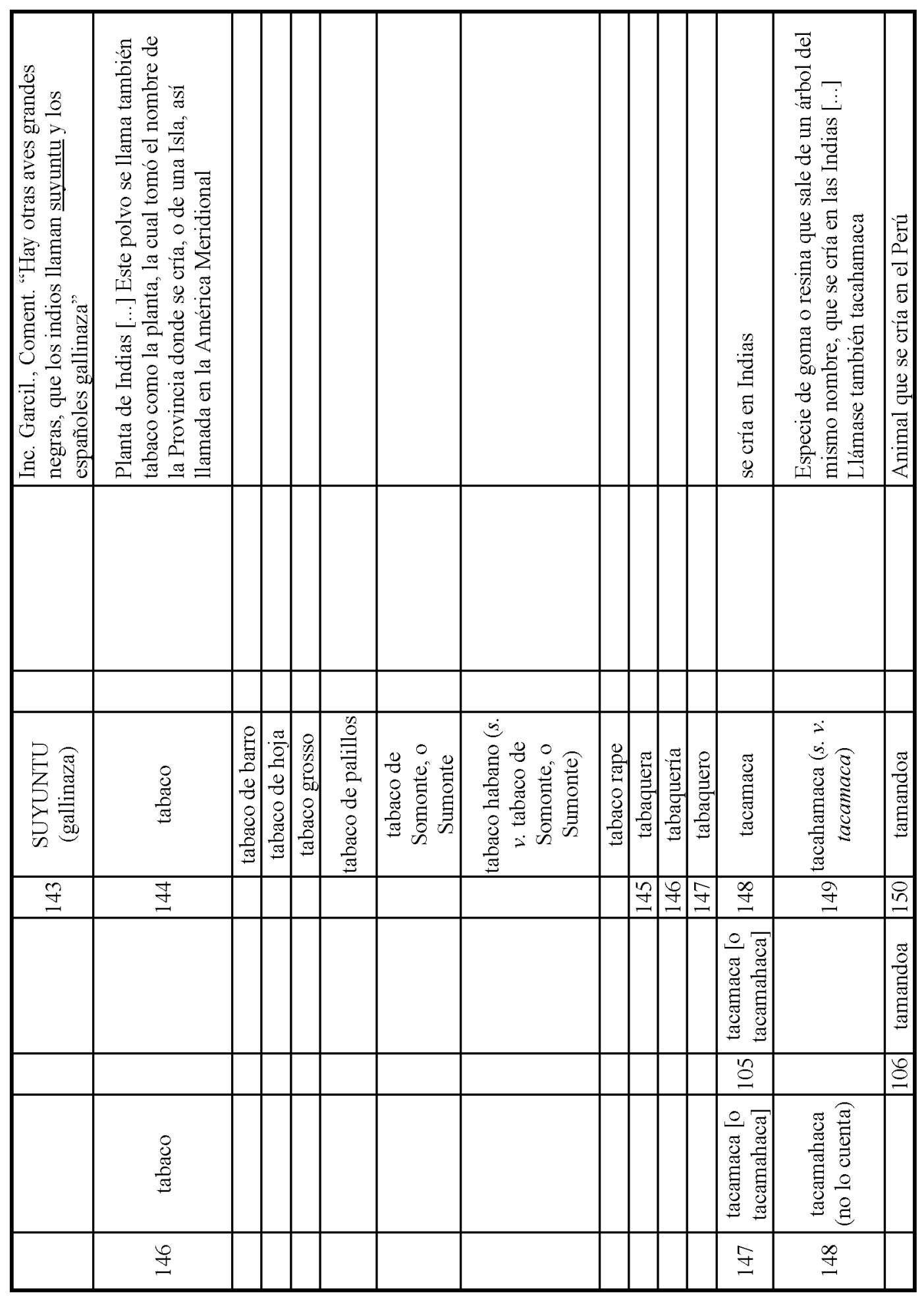




\begin{tabular}{|c|c|c|c|c|c|c|c|c|c|c|c|c|c|c|}
\hline 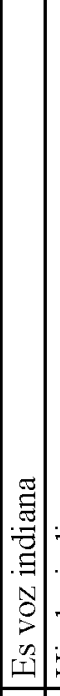 & 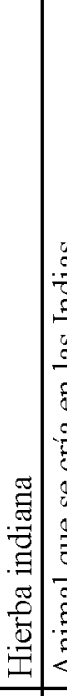 & 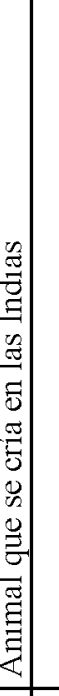 & 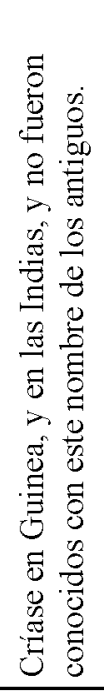 & & 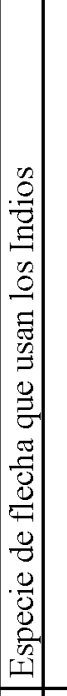 & & 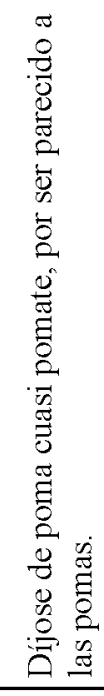 & 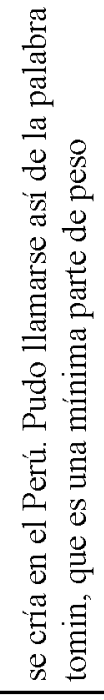 & 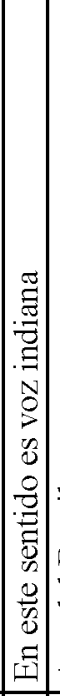 & 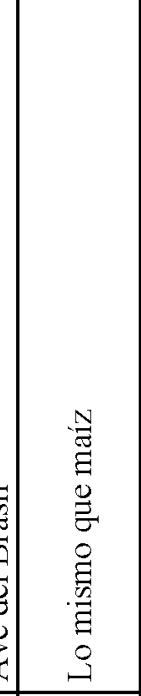 & 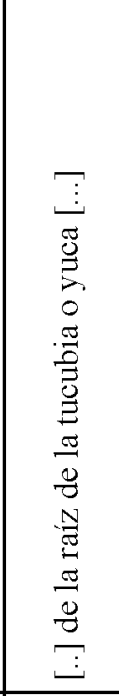 & 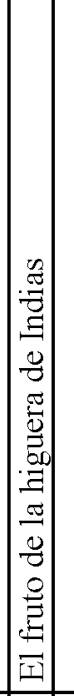 & & 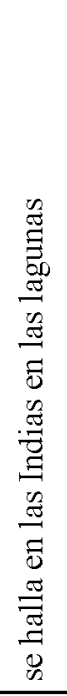 \\
\hline & 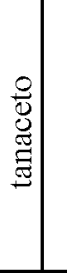 & & & & 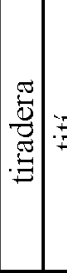 & & & $\begin{array}{l}\text { 过 } \\
\text { 离 }\end{array}$ & & 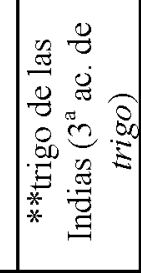 & 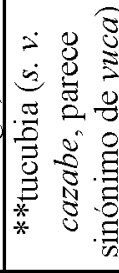 & & & \\
\hline & $\stackrel{0}{\circ}$ & & & & 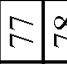 & & & 2 & & $\infty$ & $\vec{\infty}$ & & & \\
\hline 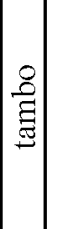 & & 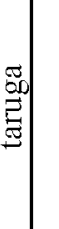 & 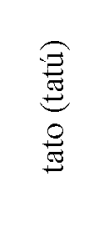 & 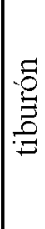 & & $\mid$\begin{tabular}{l|}
$\pi$ \\
0 \\
0 \\
0 \\
$:$ \\
0 \\
0 \\
0
\end{tabular} & 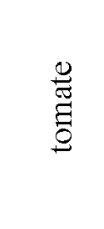 & & \begin{tabular}{|c|}
2 \\
8 \\
$\approx$ \\
0 \\
0 \\
8 \\
0 \\
0
\end{tabular} & & & $\stackrel{\Xi}{\Xi}$ & $\Xi$ & \\
\hline 몽 & & $\begin{array}{c}0 \\
n \\
n\end{array}$ & $\Omega$ & II & & \begin{tabular}{|l|l|}
$n$ \\
\end{tabular} & $\stackrel{2}{2}$ & & in & & & is & $\begin{array}{l}8 \\
-9 \\
\end{array}$ & \\
\hline : & 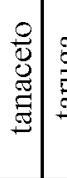 & $\begin{array}{l}\text { 品 } \\
\text { ב్ } \\
\Xi\end{array}$ & 兽 & & & & & 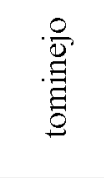 & $\begin{array}{l}0 \\
0 \\
\tilde{c} \\
0 \\
0 \\
8 \\
8 \\
0 \\
0\end{array}$ & & & 音 & & \\
\hline 5 & $\stackrel{8}{\infty} 9$ & 8 & $\stackrel{\varrho}{\varrho}$ & & & & & $\Xi$ & 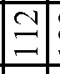 & & & $\exists$ & & \\
\hline 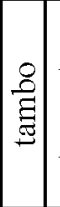 & 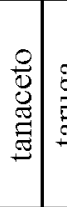 & 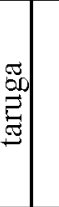 & & & 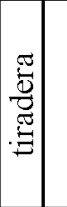 & & & $\begin{array}{l}\text { 离 } \\
\text { 禀 }\end{array}$ & \begin{tabular}{|l|} 
\\
0 \\
0 \\
0 \\
0 \\
0 \\
0 \\
0 \\
\end{tabular} & 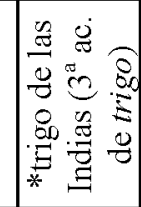 & & 音 & & 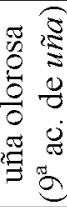 \\
\hline 呑 & : & $\overrightarrow{2}$ & & & $\stackrel{\Omega}{2}$ & & & $\hat{n}$ & : & in & & : & in & $\stackrel{\infty}{n}$ \\
\hline
\end{tabular}




\begin{tabular}{|c|c|c|c|c|c|c|c|c|c|c|c|c|}
\hline 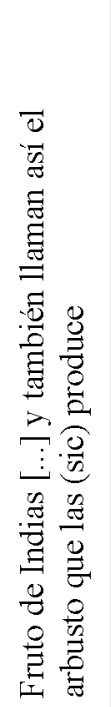 & 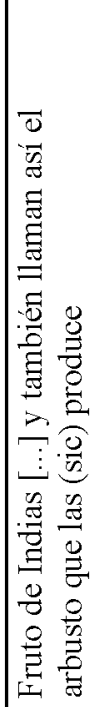 & & 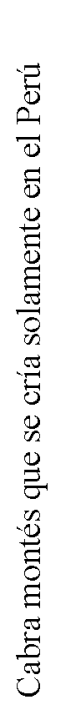 & 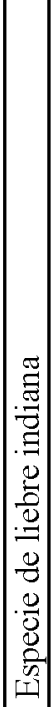 & 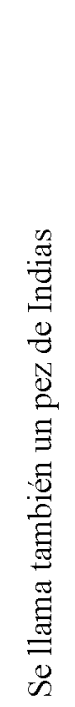 & 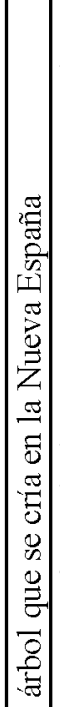 & 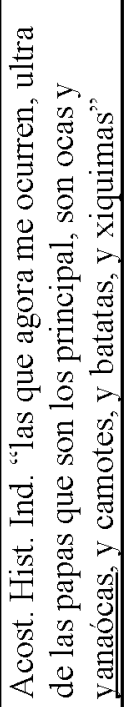 & 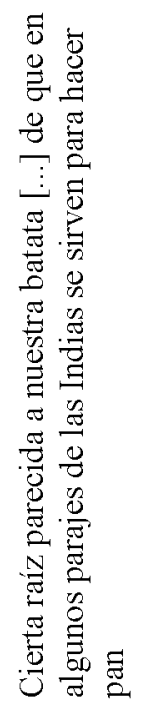 & 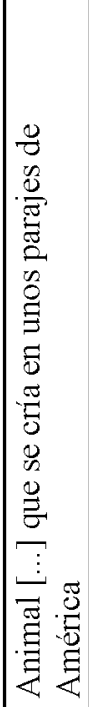 & 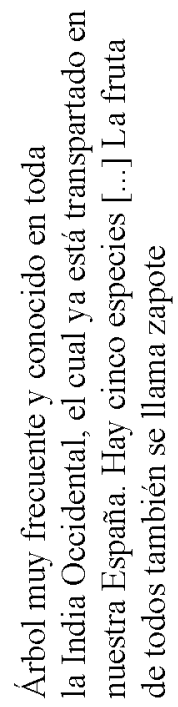 & & \\
\hline 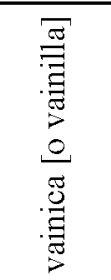 & 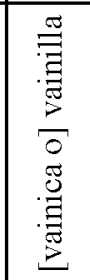 & & & & 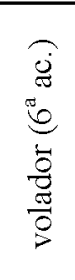 & & & & 急 & & & \\
\hline \multirow[t]{3}{*}{$\infty$} & $\infty$ & & & & $\Phi$ & & & & $\infty$ & & & \\
\hline & & 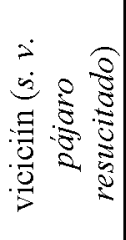 & 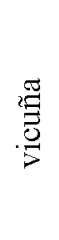 & 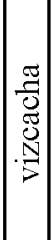 & & 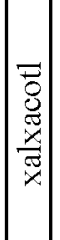 & 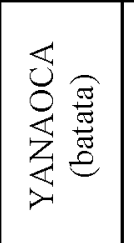 & 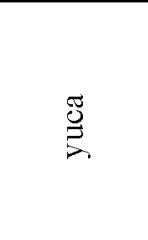 & & 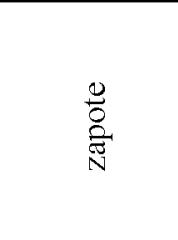 & 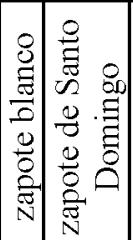 & 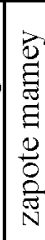 \\
\hline & & $\underline{\square}$ & $\underline{\widetilde{C}}$ & 3 & & 吾 & $\underline{6}$ & $\stackrel{8}{0}$ & & $\underline{6}$ & & $\infty$ \\
\hline 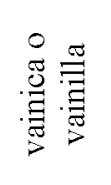 & 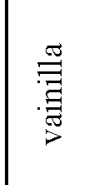 & 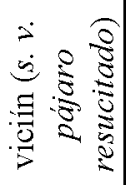 & $\begin{array}{l}\frac{\pi}{\tilde{J}} \\
\frac{0}{7}\end{array}$ & 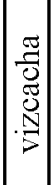 & $\begin{array}{l}\frac{\pi}{0} \\
\frac{\vec{g}}{0} \\
\frac{\pi}{8} \\
\frac{8}{8}\end{array}$ & 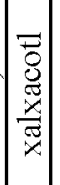 & & 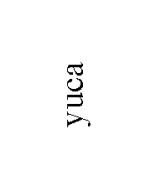 & & 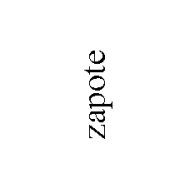 & & \\
\hline$\stackrel{10}{=}$ & $\stackrel{0}{=}$ & $\Xi$ & $\stackrel{\infty}{=}$ & $\stackrel{\Omega}{\theta}$ & $\stackrel{\text { తి }}{.}$ & $\vec{\triangle}$ & & I & & $\hat{\mathrm{I}}$ & & \\
\hline 怘 & 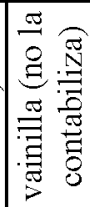 & 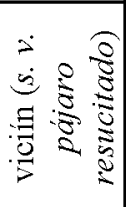 & . & $\begin{array}{l}\frac{\pi}{0} \\
\frac{d}{0} \\
. \\
\end{array}$ & 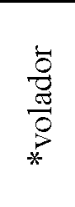 & 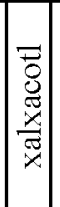 & & 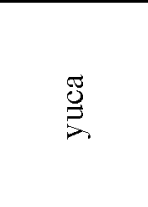 & $\begin{array}{l}8 \\
\stackrel{8}{\mathbb{N}} \\
\text { * }\end{array}$ & 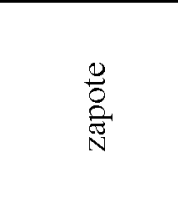 & & \\
\hline in & $\stackrel{8}{-1}$ & $\underline{\sigma}$ & $\underline{\sigma}$ & 6 & $\underset{0}{\mathbb{O}}$ & 6 & & $\ddot{\theta}$ & $\tilde{\sigma}$ & $\stackrel{\infty}{0}$ & & \\
\hline
\end{tabular}




\begin{tabular}{|c|c|c|c|c|c|}
\hline & 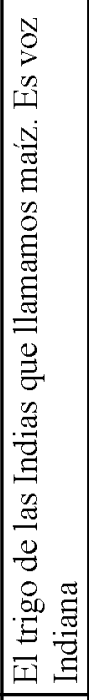 & 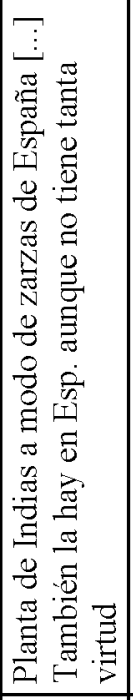 & 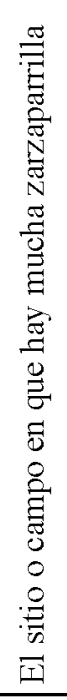 & 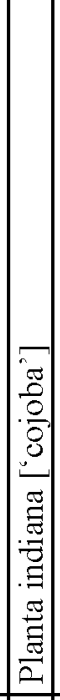 & 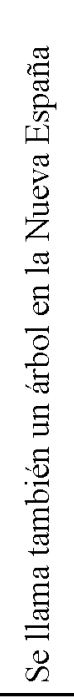 \\
\hline & & 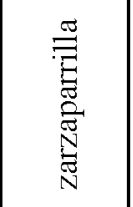 & 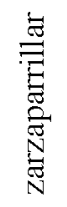 & & \\
\hline & & 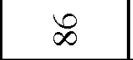 & $\grave{\infty}$ & & \\
\hline 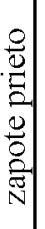 & 苋 & & & $\begin{array}{c}\pi \\
0 \\
0 \\
0 \\
0 \\
0\end{array}$ & 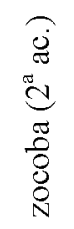 \\
\hline & $\hat{b}$ & & & 尺 & $\bar{I}$ \\
\hline & 芯 & 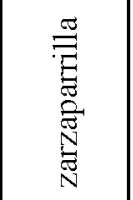 & 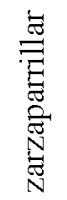 & 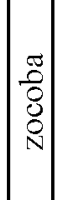 & 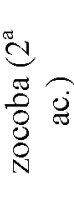 \\
\hline & I & 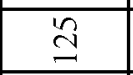 & 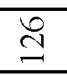 & $\widehat{\beth}$ & $\stackrel{\infty}{\unlhd}$ \\
\hline & 芯 & 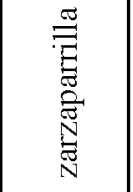 & & $\begin{array}{l}\pi \\
0 \\
8 \\
0 \\
N\end{array}$ & \\
\hline & g & $\stackrel{શ}{I}$ & & ㄱ. & \\
\hline
\end{tabular}

